Opinion

\title{
The Role of Daylight for Humans: Gaps in Current Knowledge
}

\author{
Mirjam Münch ${ }^{1, *}$, Anna Wirz-Justice 2,3(D), Steven A. Brown ${ }^{4}$, Thomas Kantermann ${ }^{5,6} \mathbb{C}_{\text {, }}$ \\ Klaus Martiny ${ }^{7}{ }^{\circledR}$, Oliver Stefani ${ }^{2,3}{ }^{(\mathbb{D}}$, Céline Vetter ${ }^{8}{ }^{(0}$, Kenneth P. Wright Jr. ${ }^{8,9}$, \\ Katharina Wulff ${ }^{10,11}$ and Debra J. Skene ${ }^{12}$ \\ 1 Sleep/Wake Research Centre, Massey University Wellington, Wellington 6021, New Zealand \\ 2 Centre for Chronobiology, Psychiatric Hospital of the University of Basel, 4002 Basel, Switzerland; \\ anna.wirz-justice@unibas.ch (A.W.-J.); Oliver.Stefani@upk.ch (O.S.) \\ 3 Transfaculty Research Platform Molecular and Cognitive Neurosciences (MCN), University of Basel, \\ 4002 Basel, Switzerland \\ 4 Chronobiology and Sleep Research Group, Institute of Pharmacology and Toxicology, University of Zürich, \\ 8057 Zürich, Switzerland; steven.brown@pharma.uzh.ch \\ 5 Faculty for Health and Social Affairs, University of Applied Sciences for Economics and Management (FOM), \\ 45141 Essen, Germany; thomas.kantermann@fom.de \\ 6 SynOpus, 44789 Bochum, Germany \\ 7 Psychiatric Center Copenhagen, University of Copenhagen, Rigshospitalet, 2100 Copenhagen, Denmark; \\ Klaus.Martiny@regionh.dk \\ 8 Department of Integrative Physiology, University of Colorado Boulder, Boulder, CO 80309, USA; \\ Celine.Vetter@Colorado.EDU (C.V.); Kenneth.Wright@colorado.edu (K.P.W.J.) \\ 9 Division of Endocrinology, Metabolism and Diabetes, University of Colorado, Aurora, CO 80045, USA \\ 10 Departments of Radiation Sciences and Molecular Biology, Umeå University, 90187 Umeå, Sweden; \\ katharina.wulff@umu.se \\ 11 Wallenberg Centre for Molecular Medicine (WCMM), Umeå University, 90187 Umeå, Sweden \\ 12 Chronobiology, Faculty of Health and Medical Sciences, University of Surrey, Guildford GU2 7XH, UK; \\ d.skene@surrey.ac.uk \\ * Correspondence: m.munch@massey.ac.nz
}

Received: 31 October 2019; Accepted: 21 February 2020; Published: 28 February 2020

\begin{abstract}
Daylight stems solely from direct, scattered and reflected sunlight, and undergoes dynamic changes in irradiance and spectral power composition due to latitude, time of day, time of year and the nature of the physical environment (reflections, buildings and vegetation). Humans and their ancestors evolved under these natural day/night cycles over millions of years. Electric light, a relatively recent invention, interacts and competes with the natural light-dark cycle to impact human biology. What are the consequences of living in industrialised urban areas with much less daylight and more use of electric light, throughout the day (and at night), on general health and quality of life? In this workshop report, we have classified key gaps of knowledge in daylight research into three main groups: (I) uncertainty as to daylight quantity and quality needed for "optimal" physiological and psychological functioning, (II) lack of consensus on practical measurement and assessment methods and tools for monitoring real (day) light exposure across multiple time scales, and (III) insufficient integration and exchange of daylight knowledge bases from different disciplines. Crucial short and long-term objectives to fill these gaps are proposed.
\end{abstract}

Keywords: natural light; spectrum; twilight; circadian rhythms; melatonin; entrainment; health; sleep; alertness; mood 


\section{Introduction: The Need to Identify Current Gaps of Knowledge in Daylight Research}

Our rotating planet, with its alternating 24-h light-dark cycles, changing day lengths with seasons, and weather conditions, has major effects on the physiology and behaviour of organisms from prokaryotes to mammals. One adaptive response to this dynamically changing geophysical environment in most organisms has been the evolution of biological time-keeping systems, i.e., biological "clocks" capable of synchronisation (entrainment) to environmental time cues, providing the enormous advantage of anticipation to environmental changes, allowing corresponding adaptations in behaviour (e.g., shelter, reproduction) and physiology (e.g., metabolism, quiescence). Since the early 1980s, it is known that many aspects of biological clock function are highly conserved across species, for example, the intracellular structure of clocks themselves, a feedback loop encoded by dedicated "clock genes" first described in fruit flies [1,2] and later in mammals [3]. Another highly conserved evolutionary mechanism is (day-) light perception via specialised light-sensitive molecules in specific cells on the outer surface of multicellular organisms. Within the animal kingdom, opsins are the common photopigment molecules of all visual systems [4,5]. A unique ancestral photopigment melanopsin-highly conserved and considered the evolutionary linkage between invertebrate and vertebrate photopigments-plays a special role in so-called nonvisual light perception, including circadian photoentrainment [6-8]. The intrinsically photosensitive properties of melanopsin were first described in frog skin [9], and later in mammalian eyes [10-12], including humans [13]. These examples emphasise the fact that important time-keeping processes supporting adaptation to the natural day-night environment evolved over a large time scale (millions of years).

Only very recently on this time scale, i.e., less than 200 years ago, technical progress-the discovery of electric lighting (and electric power)—enabled, for the first time, relative independence from (natural) daylight. Even though this invention has been of great benefit for humankind, it has also thoroughly and irreversibly changed our home, social and work environments. There are two main reasons for these changes: Firstly, relative independence from the natural light-dark cycle fostered 24/7 work and living conditions throughout the developed world. Secondly, the use of electric lighting has not only been restricted to night time but has also made it possible to live and work independently of daylight during the day. There is now growing evidence that these changes have had broad consequences for health ${ }^{1}$ issues worldwide (see, e.g., [14]).

One aspect of these health consequences relates to inadequate "entrainment" of biological clocks to electric light. Entrainment is an active process by which environmental time cues, zeitgebers (German for "time cue"), such as the light-dark cycle, produce stable and appropriate timing of internal biological clocks [15-17]. Within the biological rhythm research community, there are concerns about the weakness of zeitgeber strength for circadian entrainment in electrically lit environments (with no or low natural daylight exposure). Circadian disruption, as a consequence of inadequate entrainment, could impact on robustness, regularity, and amplitude of biological rhythms in individuals and within different populations [18]. Adverse health effects, in which the lack of sufficient daylight has been directly (daily light and dark exposure) or indirectly (via circadian misalignment) involved, range from sleep problems and impaired daytime functioning to increased prevalence of chronic diseases such as depression, obesity, diabetes, cardiovascular diseases and cancer [19-26].

The contribution of circadian rhythm disruption to disease pathogenesis is likely to be multifactorial. In other words, when work, social and environmental pressures disrupt the entrainment of circadian rhythms by light and non-photic zeitgebers (food, physical activity), the out-of-sync circadian physiology may predispose to altered stress levels and lifestyle changes (fatty diet, alcohol consumption, smoking, self-medication, lack of exercise, short sleep). Together, this will alter multiple brain and body circuits that underpin physical and mental health, representing a multifactorial basis for any form of pathophysiology $[27,28]$.

Scheduled daylight and mixed daylight/electric light exposure conditions may also optimise the effectiveness of certain medications/drugs and reduce side effects directly or indirectly via inducing robust circadian rhythmicity [29]. The latter would enable timed coordination between the kinetics of a 
drug's actions and the host's responsiveness. However, we are just at the beginning of understanding these points, and replication and further larger-scale studies are warranted.

To some individuals, the idea that the light environment has the potential to significantly influence human health outcomes may seem exaggerated. However, this is long established in the commercial application of light (photoperiod, intensity, and spectral balance of wavelengths) in growing plants, flowers, fruits, poultry and livestock [30], though with emerging negative consequences from climate change [31]. Humans may similarly require exposure to specific light patterns for optimal physiological and psychological well-being.

Given the primordial role of light for the circadian system and other non-visual functions and the regulatory role of the circadian system on a multitude of physiological processes, it is crucial to identify (and address) current gaps in daylight research. In this report, we use the term "daylight" to comprise mixed daylight/electric light conditions, which is thus implicitly included throughout the manuscript if not stated otherwise. With respect to health, daylight research should also include the development of coping strategies against chronically altered (day-) light conditions, such as experienced in atypical work schedules, including shift work. Daylight research may also elucidate how adequate daylight exposure could maintain health, prevent disease, and reduce circadian disruption. The main goals of daylight research in a human context are thus: (1) To elucidate the effectiveness of daylight to promote general health, quality of life and foster coping strategies. (2) To develop standardised tools to accurately and continuously measure daylight (and electric light) as well as methodologies to determine its effects on visual, psychological, and somatic functions. (3) To translate existing knowledge about human responses to daylight into appropriate designs for daylight-enhanced buildings and urban settings at the planning stage. This paper addresses these three goals by identifying main knowledge gaps, defining related, unanswered questions, and suggesting possible ways to fill these gaps and develop potential coping strategies.

To identify gaps of knowledge in daylight and to address them is complex because the implications of daylight go far beyond isolated and specialised research areas; they impact broadly on many disciplines such as science of the built environment (physics, engineering, architecture), environmental sciences, medicine, psychology, economics, occupational and social sciences. The unanswered questions related to daylight research are those which have been explored under electric light conditions (mostly in the laboratory) but have not yet been answered for daylight research (which is mainly related to daylight inside buildings). There are questions that are specific to daylight and cannot be (easily) mimicked by electric light (e.g., seasonal changes in day length or twilight conditions). Also, some questions and problems have to date not been addressed either with daylight or electric light. Our report is designed to highlight some of these questions and put daylight into the focus of research. Obviously, quantities and qualities can vary considerably between daylight and electric light, especially inside buildings, and to date, it is unknown whether daylight is superior to electric lighting with respect to the impact on humans (and if so why).

This paper was developed from an interdisciplinary workshop involving members of the Daylight Academy (DLA; www.daylight.academy) in November 2017 in Lausanne (Switzerland). The "missing links" in defining the biological value of daylight (and darkness at night) for human beings were discussed with respect to vast regional differences in daylight availability across the year from the equator to high latitudes. A second meeting took place in June 2018 in Berlin (Germany) to discuss the role of daylight and specify gaps and barriers to the advancement in knowledge. Therefore, the workshop outcome is obviously primarily focused on daylight. In addition, specific action points were named to achieve the goals. These goals include evidence-based knowledge-transfer for enabling practitioners to design living and working spaces and conditions in a regional-adapted manner for the benefit of the inhabitants.

We do not systematically review the literature on the current state of daylight research or carry out a meta-analysis. Since this paper is an enlarged output of two workshops on daylight and its impact on humans, it differs in its formal structure from an experimental study. 
This report is envisaged as a framework for stimulating interdisciplinary research and collaborative approaches to the neglected area of daylight research in humans. During the DLA workshops, we came up with a list of gaps, which were retrospectively assigned to three main groups (Figure 1): (I) Lack of knowledge regarding the quantity and quality of daylight needed for "optimal" physiological and psychological functioning (optimal = relating to best possible quality of life for an individual); (II) Lack of consensus on practical measurement and assessment methods and tools for real (day-) light exposure across multiple time scales, especially under long time recording periods (e.g., circadian, seasonal contexts); and (III) insufficient integration and exchange of knowledge bases related to daylight from different disciplines. This grouping is not based on any a priori concept, but rather grew out of the two workshops and meetings within the DLA. A summary of the many physical differences between the properties of daylight and electric light have been recently published by members of the DLA [30,32].

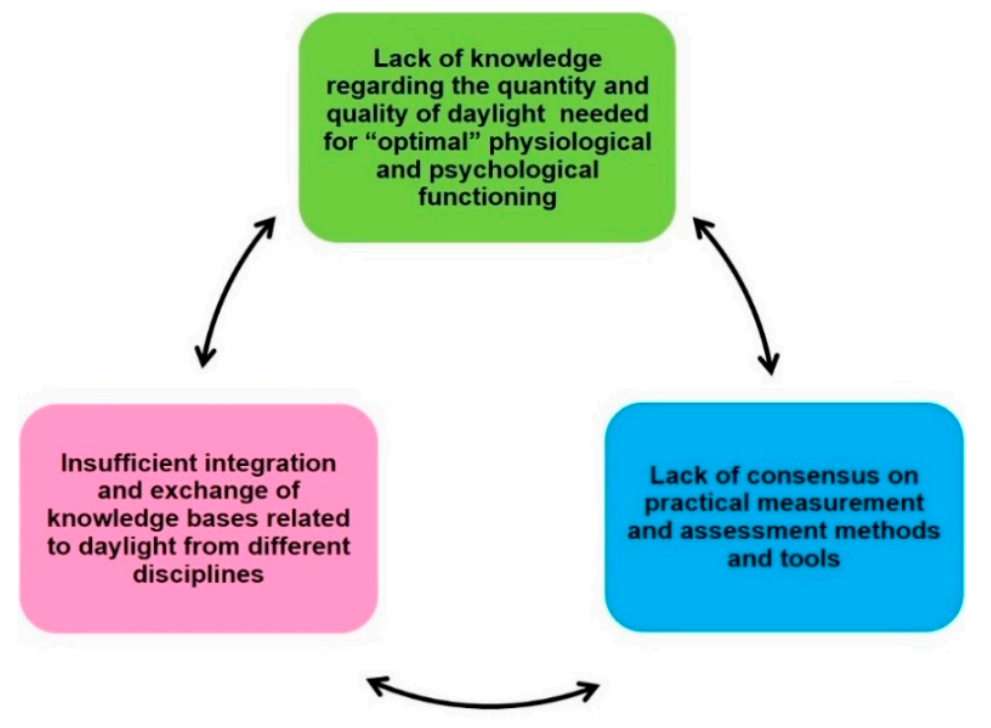

Figure 1. The identified three main groups of gaps of knowledge in daylight research.

\section{Gaps Group I: Lack of Knowledge Regarding Quantity and Quality of Daylight Needed for “Optimal” Physiological and Psychological Functioning}

We live in a global and increasingly digitised 24/7 society. Among the key gaps in daylight research is the lack of knowledge about timed combinations of quantity and quality of daylight (including mixed day/electric light conditions) required by a given individual each day. This information is necessary to cope with and mitigate challenges arising from electrically lit life and work conditions. The term "optimal" hereby refers not to an absolute value, but rather to the best possible quality of life for an individual under his or her environmental conditions. Lighting standards for the visual system have been developed; here, we focus primarily on the non-visual physiological and psychological functions. This first group of gaps in daylight research contains a variety of different subgroups: (Section 2.1) vision and visual comfort; (Section 2.2) physiology and behaviour; (Section 2.3) circadian entrainment; (Section 2.4) "optimal" (day-) light dose; (Section 2.5) light sensitivity; (Section 2.6) therapeutic aspects; (Section 2.7) risks; (Section 2.8) inter-individual differences; (Section 2.9) work conditions; and (Section 2.10) environmental factors.

\subsection{Open Questions for the Effects of Daylight on Vision and Visual Comfort}

The effects of electric light on vision (e.g., [33,34]), or light conditions for vision at workplaces (e.g., [35]) were extensively explored many decades ago, but it is still not clear whether there are daylight-specific influences on vision, visual capabilities, visual processing and comfort, which may arise from the physical differences between daylight and electric light [32]. More specifically: 
- Daylight impacts on vision and visual comfort with respect to colour perception [36], colour preferences (e.g., [37]), as well as homogeneity, dynamics, glare and flicker from mixed daylight/electric lighting conditions (e.g., [38]).

- There is considerable literature on visual comfort and glare evaluations with daylight inside buildings, e.g., [39], but very little is known about mixed/synergistic effects of high visual comfort together with non-visual functions such as alertness, mood [40-42] and indoor temperature perception [43,44]. These mixed/synergistic effects are missing not only for daylight but also for mixed electric/daylight conditions.

\subsection{How Does Daylight Impact on Physiology and Behaviour Beyond Vision?}

There is now a large body of evidence from human studies on the non-visual physiological and psychological effects of electric light under controlled laboratory conditions (e.g., [45-62]). An increasing number of studies have also investigated the non-visual effects of daylight alone or with mixed daylight/electric light (e.g., [43,63-68]), which better reflects the situation at most work and residential places. A big difference with daylight is, of course, that there is also usually a view, i.e., being outdoors or looking out of the window into green (or built) spaces, to the sky, which per se is positively rated [69-71]. Some examples of knowledge gaps in daylight research for five non-visual functions are shown in Table 1.

Table 1. Some open questions in mixed electric light/daylight research related to metabolic functions, sleep, alertness and cognition as well as physical activity.

\begin{tabular}{|c|c|}
\hline \multicolumn{2}{|l|}{ (i) Metabolic functions } \\
\hline $\begin{array}{l}\text { How does electric light and/or } \\
\text { daylight affect } \\
\text { metabolic functions? }\end{array}$ & $\begin{array}{l}\text { This question is closely related to meal timing, caloric intake and meal composition, or weight loss. A } \\
\text { few studies have investigated these aspects under laboratory conditions [72-74], but not yet under } \\
\text { daylight conditions. The question is whether daylight exposure specifically affects the timing of meals, } \\
\text { post-prandial responses, temperature regulation, metabolism, body composition and the gut } \\
\text { microbiome? }\end{array}$ \\
\hline \multicolumn{2}{|l|}{ (ii) Sleep } \\
\hline $\begin{array}{l}\text { How do daylight-specific } \\
\text { properties affect alertness and } \\
\text { cognitive functions? }\end{array}$ & $\begin{array}{l}\text { Many laboratory studies with steady state electric lighting showed light-dependent } \\
\text { alertness }[45,46,49,81-83] \text { and cognitive repercussions }[46,53,55] \text {. A few studies have looked at } \\
\text { spectrally tuned electrical light conditions and alertness and cognition }[76,84-86] \text {. }\end{array}$ \\
\hline \multicolumn{2}{|l|}{ (iv) Physical activity } \\
\hline $\begin{array}{l}\text { Does physical activity and daylight } \\
\text { interact to induce larger phase } \\
\text { shifts of the circadian clock? }\end{array}$ & $\begin{array}{l}\text { From studies in the laboratory there is a phase-response curve of physical activity with both phase } \\
\text { delays and advances at specific times of day [87]. Activity facilitates phase delays in very dim } \\
\text { light [88]. The question relates to the interaction of exercise with (day-) light exposure as shown with } \\
\text { cycling performance [89]. }\end{array}$ \\
\hline
\end{tabular}

\subsection{Gaps of Knowledge on Circadian Entrainment}

Most chronobiological research in humans over the past 50 years has mainly dealt with (controlled) electric light in the laboratory, "bunkers" or caves [90-97]. The biggest issue here is certainly removal from any natural photic context and reduced external stimuli. These studies were necessary to understand what we currently know, but now it is time to move to more naturalistic approaches, including studying daylight, and/or mixed electric light/daylight during the daytime [98]. Surprisingly, there are only a few studies looking at circadian entrainment in humans under natural conditions $[78,79]$, and most of them have been short-term studies. There is evidence from a few isolated populations, 
still living without electric lighting, that the circadian phase of entrainment relative to the external light-dark cycle is indeed different from that in regions supplied with electric light sources [99]. There is a considerable gap of knowledge about the impact of natural light under real-life conditions, as summarised in Table 2.

Table 2. Gaps in knowledge about the impact of natural light under real-life conditions.

\begin{tabular}{|c|c|}
\hline \multicolumn{2}{|r|}{ Daylight and Circadian Entrainment } \\
\hline $\begin{array}{l}\text { (i) Daylight properties: } \\
\text { Quality/quantity }\end{array}$ & $\begin{array}{l}\text { Which combinations of daylight qualities and quantities are relevant for circadian } \\
\text { entrainment (alone and in combination with electric light sources) and dependent } \\
\text { on time of day? }\end{array}$ \\
\hline Spectrum/colour & $\begin{array}{l}\text { Which frequency bands of the electromagnetic spectrum are relevant when and } \\
\text { how important is the integration of colour [100]? }\end{array}$ \\
\hline Dynamics & Do ultradian variations/dynamics of daylight play a role in circadian entrainment? \\
\hline Twilight & $\begin{array}{l}\text { What is the role of twilight (dawn and dusk) for circadian entrainment in humans } \\
{[101,102] \text { ? For example, is the colour signal of the "blue hour" as important for }} \\
\text { humans as it is for mice }[103,104] \text { ? }\end{array}$ \\
\hline Polarisation of daylight & $\begin{array}{l}\text { What is the role of polarised daylight? Direct sunlight is not polarised but daylight } \\
\text { from a particular region of the sky is partially polarised. In contrast to bees, humans } \\
\text { can hardly perceive polarised light, however a physiological influence of polarised } \\
\text { light on humans cannot yet be excluded. A study by Brainard et al. showed no } \\
\text { difference between unpolarised and polarised light on melatonin suppression [105]. }\end{array}$ \\
\hline $\begin{array}{l}\text { Role of light distribution in the } \\
\text { visual field, direction of light }\end{array}$ & $\begin{array}{l}\text { A further characteristic of daylight is its large-area expansion with an unobstructed } \\
\text { view of the sky. Non-human primates have ipRGcs distributed over the entire } \\
\text { retina with a density of } 3-5 \text { cells } / \mathrm{mm}^{2} \text {, and a maximum concentration of } 20-25 \\
\text { cells } / \mathrm{mm}^{2} \text { around the fovea [106]. Since rods, cones and the ipRGCs in the eye are } \\
\text { distributed over large areas of the retina, it is assumed that the non-visual effect of } \\
\text { light is greatest when the light comes from a large source, such as an indirect } \\
\text { illumination of a large bright area. In nature, this light comes from the sky. If only a } \\
\text { small area of the retina is illuminated, as is the case with directed light from a spot, } \\
\text { a weaker non-visual effect is assumed. The direction of light seems to be crucial at } \\
\text { least for electric light that was shown to affect melatonin suppression [107-109] and } \\
\text { sleep [110]. }\end{array}$ \\
\hline Season, latitude and day length & $\begin{array}{l}\text { Does photoperiod length impact on circadian entrainment? From the literature it is } \\
\text { known that there are differences in humans under purely natural seasonal lighting } \\
\text { conditions when compared to mixed natural/electric light conditions }[78,79,111] \text {. }\end{array}$ \\
\hline (ii) Effect on peripheral tissues & $\begin{array}{l}\text { How does electric light and/or daylight (indirectly) influence peripheral clock tissue } \\
\text { function (e.g., metabolism, immune function, cardiovascular function, cell repair, } \\
\text { detoxification, mitochondrial turnover)? }\end{array}$ \\
\hline $\begin{array}{l}\text { (iii) Circadian } \\
\text { misalignment/disruption }\end{array}$ & $\begin{array}{l}\text { How can electric and/or daylight help to mitigate circadian misalignment/circadian } \\
\text { disruption (e.g., in shift workers [112-114], adolescents)? }\end{array}$ \\
\hline
\end{tabular}

\subsection{What Is the "Optimal" Dose of Daylight with Respect to Intensity, Spectrum and Timing?}

From laboratory studies with electric lighting interventions during the daytime, mixed dose-response effects have been reported for intensity, duration and spectral composition: Some studies found effects of daytime/evening electric light exposure on subjective and/or objective variables $[52,86,89,115]$, while others did not $[82,116]$. Few studies have been conducted under daylight conditions only or mixed daylight/electric light conditions, and most of these are applied or semi-natural studies $[40,65,78]$. The general unanswered questions are related to daylight thresholds, duration/intensity and spectral responses, as well as the role of the dynamics of daylight. To date, these complex daylight properties have not been evaluated in a single model. There is evidence of a complex interaction between different subtypes of ipRGC (modulated by rod and cone input), which depend on the daylight spectrum and irradiance [117]. Finally, the main question also remains-why should daylight be different from findings with electric light? The outstanding questions are summarised in Table 3. 
Table 3. Unanswered questions related to properties of daylight and or electric light indoor lighting conditions.

\begin{tabular}{|c|c|}
\hline Spectral range & $\begin{array}{l}\text { Does the fact that the spectral power distribution of daylight goes beyond the visible range make a difference for non-visual functions, when } \\
\text { compared to electric light? For example, the infrared (IR) portion that is always present in daylight is non-existent in electric light (except for banned } \\
\text { incandescent light sources). It might have an important role for the retina, since a large body of literature suggests connections between } \\
\text { long-wavelength radiation and (beneficial) physiological functions in the retina (see e.g., [118,119]). In addition, there is probably a specific role of } \\
\text { the spectral power distribution and colour of twilight, as shown in rodents [103,104]. }\end{array}$ \\
\hline Duration and thresholds & $\begin{array}{l}\text { - What are daylight or mixed electric/daylight exposure durations }[52,120] \text { and thresholds for non-visual functions, under real life circumstances? } \\
\text { - What is the threshold of daylight/electric light conditions in the evening/night that does not interfere with sleep onset/propensity? }\end{array}$ \\
\hline Dose-response relationships & $\begin{array}{l}\text { What are the dose-response relationships for daylight and mixed daylight/electric light exposures for non-visual functions? In particular, with regard } \\
\text { to the interaction of circadian and homeostatic processes with environmental conditions - that include electric light. }\end{array}$ \\
\hline & Daylight is spatially and temporally variable. These changes take place over very wide frequency bands: \\
\hline Irradiance and spectral composition & $\begin{array}{l}\text { What are these frequency bands, irradiances and are these variations required for the circadian system and other non-visual functions? } \\
\text { - What is the influence of different contrasts of daylight or mixed electric light/daylight for photoreceptors (i.e., high vs. low melanopic } \\
\text { irradiance) as was shown for electric light on visual perception [121], pupil light reflex and alertness [84,86]? }\end{array}$ \\
\hline 24 h-Dynamics & How do the 24-h dynamics of daylight impact on non-visual functions? \\
\hline Light history & How can prior light history (see Table 4) of any light exposure be incorporated into the above-mentioned outcomes? \\
\hline Therapeutic use of light & $\begin{array}{l}\text { Light treatment has been established for winter and other depressive disorders and circadian sleep disturbances [122-125]. What should the daylight } \\
\text { exposure recommendations be for these different therapeutic interventions (regarding intensity, spectrum, timing and prior light exposure)? }\end{array}$ \\
\hline
\end{tabular}




\subsection{How Does Daylight Influence Light Sensitivity Functions?}

There are a few field and laboratory studies showing indirectly that sensitivity to light increases when there is a lack of daylight or predominantly low indoor light exposure [126-130], but there is no consensus how to measure light sensitivity nor about the length of daylight nor the mixed electric light/daylight exposure necessary to counteract such increased sensitivity. This is of great importance since chronic exposure to low daylight levels during daytime may increase vulnerability to light in the evening/night due to increased sensitivity, as shown under electric light [80,131,132].

Another aspect of daylight and retinal functions is the question of underlying mechanisms and counterstrategies for the recent high increase of myopia cases in children (e.g., South East Asia). Growing evidence suggests that chronic low daylight exposure is one of the possible triggering factors; for a recent review, see [133].

\subsection{Is Daylight Exposure Effective as a 'Treatment'?}

There is clear evidence for the therapeutic use of controlled bright and/or dynamic light exposure (with or without daylight) in hospitals and nursing homes [134-138], as well as light therapy lamps for a variety of psychiatric (e.g., seasonal and non-seasonal affective disorder, bipolar depression [123-125], ADHD [139], borderline personality disorder [140]), neurologic (Parkinson's disease [141,142]), and medical disorders to improve sleep (e.g., [143]) or reduce fatigue [144]. Only a few studies have explored scheduled daylight exposure for therapeutic use to obtain information about duration and timing as related to improvement [145-148].

The question is why not use daylight instead of light therapy lamps since daylight is freely available and without energy costs, and there are other beneficial effects with daylight exposure such as a view, contact with nature, other people? There is, at present, insufficient evidence to replace light therapy lamps with timed daylight as treatment for the above indications. It would be important—and practical— to know if daylight is equally effective or even superior to electric light as therapy. One study in seasonal affective disorder suggested outdoor light is equivalent in response [145]. We need to know if regular daylight exposure or mixed electric light/daylight (and darkness at night) enhances recovery/promotes health in hospitalised patients more efficiently (e.g., post-surgery, intensive care [149-151]), and in healthcare institutions (e.g., psychiatric wards, nursing homes $[152,153])$ than with electric light alone. The question arises as to which daylight interventions are needed for which groups (e.g., patients with impaired vision/visual blindness, circadian rhythm sleep-wake disorders, depression and other psychiatric/neurologic diagnoses), adolescents or older people, shift workers, men and women?

\subsection{Are There Risks of Daylight Exposures (e.g., Systemic Diseases, Dermatology, Ophthalmology)?}

Much is known about the direct UV risk from sunlight for skin and eyes in humans, and current regulations are regularly evaluated [154]. National programs to reduce skin cancer have been launched worldwide. There is, however, only very little evidence as to whether having full sun protection all the time is beneficial for other physiological functions. A recent study (performed in South Asia) showed that wearing a sun hat and sunglasses while being outside still allows a good portion of daylight to be transmitted via the eyes [155], but this finding also needs to be shown for places further from the equator.

In addition: How can light-sensitive populations be protected from too much (day-) light (e.g., porphyria patients, patients taking light-sensitising medications, photophobic patients, patients with migraine, certain patients with retinal damage, patients with skin diseases), whilst still retaining enough exposure to ensure proper/adequate functional outcomes (e.g., vitamin D synthesis, sleep quality, waking functions, circadian entrainment and general health)? 


\subsection{Gaps of Knowledge Related to Individual Differences}

We know of some factors that can explain inter-individual differences in response to light exposure, including age, chronotype, gender, genotype and many more. However, there is much more unknown, and it is not clear whether these inter-individual differences are manifested under daylight conditions. Here (Table 4), we list some of the known inter-individual "trait" differences mainly in response to electric light, which also need to be considered for daylight research (and where the mechanisms remain to be elucidated). Some of these inter-individual differences are only known for non-human species and have not yet been explored in humans. Beyond these inter-individual traits, it might also be important to know what the consequences of such differences are-for example, sex differences in the perception of light of a special quality might lead to implications on the societal aspect of gender for light applications.

Table 4. Inter-individual trait and state differences in response to electric light or mixed electric light/daylight.

\footnotetext{
(i) Physiological differences:

- $\quad$ Light sensitivity in adults [156-158] and children/adolescents [159-161], and elderly (less light transmission with age due to e.g., yellowing of the lens, cataracts [162-165], reduced pupil size [163,166]),

1. Pupil responses to light in healthy persons [167-170] and patients with eye disease [171-175]

2. Light responses depending on generalised medical and psychiatric status [176-179] and medication [180]
}

\section{(ii) Genetic differences:}

- $\quad$ Known for the clock gene PER3 [181] and epigenetic modulators [182]

- $\quad$ Genetic missense variant for melanopsin gene in seasonal affective disorder patients [183]

- Melanopsin gene polymorphism [184] revealed changes in light sensitivity- Is there genetic adaptation of light sensitivity to geographical latitude, as was suggested for a polymorphism in PER3 gene length depending on latitude [185]?

\section{(iii) Cultural, behavioural differences:}

- $\quad$ Cultural and social differences (e.g., clothing) [186,187]

- What are the societal and ethnic/cultural differences in outdoor-related behaviour [188]?

- How do various climate constraints limit going outdoors [186]?

\section{(iv) Mixed physiological/behavioural effects:}

- $\quad$ Different photic histories, due to inter-individual differences in sleep/wake patterns $[158,189]$ and/or

- $\quad$ work/social schedules [126,128,190-192] (see also below - morning/evening types),

- $\quad$ Sex/gender [193,194]

- $\quad$ Does (day-) light exposure during pregnancy and early postnatal periods play a role in individual eye development

- $\quad$ and circadian behaviour as shown in mice and rats $[195,196]$ ?

- $\quad$ Morning/evening types [197-199] (i.e., chronotypes [200,201] — which may be considered a behavioural trait or as

- $\quad$ proxy for phase of entrainment) and their preferences/choices for light $[67,202,203]$

\subsection{Gaps of Knowledge in Daylight Research for Work Conditions}

Many field studies have tested different electric light scenarios at work, but from most of the studies, it is not clear if and how daylight exposure in addition to electric light was considered for the analysis; therefore, many questions remain. In addition, many aspects related to work conditions overlap with general aspects, as mentioned in Sections 2.1-2.5, 2.7 and 2.8. Table 5 summarises some specific work and daylight associated questions: 
Table 5. Identified workplace daylight as well as mixed electric light/daylight associated questions.

\begin{tabular}{ll}
\hline $\begin{array}{l}\text { Daylight conditions for individuals } \\
\text { at workplaces }\end{array}$ & $\begin{array}{l}\text { How much and which qualities of daylight do different individuals/groups receive } \\
\text { at their work- and living places (24/7), and how does this relate to their } \\
\text { health status? }\end{array}$ \\
\hline & $\begin{array}{l}\text { Can daylight be a means to counteract the detrimental effects of "light at the wrong } \\
\text { time of day", such as occurs with light in the evening or with (night) shift work? } \\
\text { The reason might be that light during the day has a desensitisation effect for light } \\
\text { exposure in the evening (see Tables 3 and 4: light history), and in night shift } \\
\text { workers bright light exposure after daytime sleep could help readjustment to the } \\
\text { daytime work hours [204], see also recent recommendations of the 'Working Time } \\
\text { Society' (WTS/ICOH; [113]). }\end{array}$ \\
$\begin{array}{l}\text { Daylight exposure as a } \\
\text { countermeasure (for shift workers }\end{array}$ & $\begin{array}{l}\text { Are existing workspace regulations on glare and visual comfort at workplaces } \\
\text { sufficient to concomitantly provide good and 'biologically relevant' daylight } \\
\text { conditions [192]? }\end{array}$ \\
\hline $\begin{array}{l}\text { Daylight and visual comfort and } \\
\text { non-visual functions at workplaces }\end{array}$ & $\begin{array}{l}\text { How important is the view out of the window and the environment outside the } \\
\text { window [205] for workplace-related variables such as performance and alertness? }\end{array}$ \\
\hline View/window &
\end{tabular}

\subsection{Gaps in Knowledge of Daylight Research Related to Environmental Factors}

In our built environment, many factors influence the quantity and quality of daylight exposure. These mostly physical factors are per se well known, but the interactions with and consequences on humans of latitude, time zones, micro- and macroclimate, architecture and urban settings are only poorly understood (Table 6). Therefore both the spectrum and intensity of the daylight influx which reaches indoor rooms matters, and is, of course, dependent on architectural properties, building orientation, windows size, glazing, and geographical latitude. And lastly, how relevant is the concept of the "biophilia" hypothesis, which describes that humans tend to find connections with nature and living organisms, in this context (e.g., [206])?

Table 6. Gaps in knowledge of daylight research related to environmental factors.

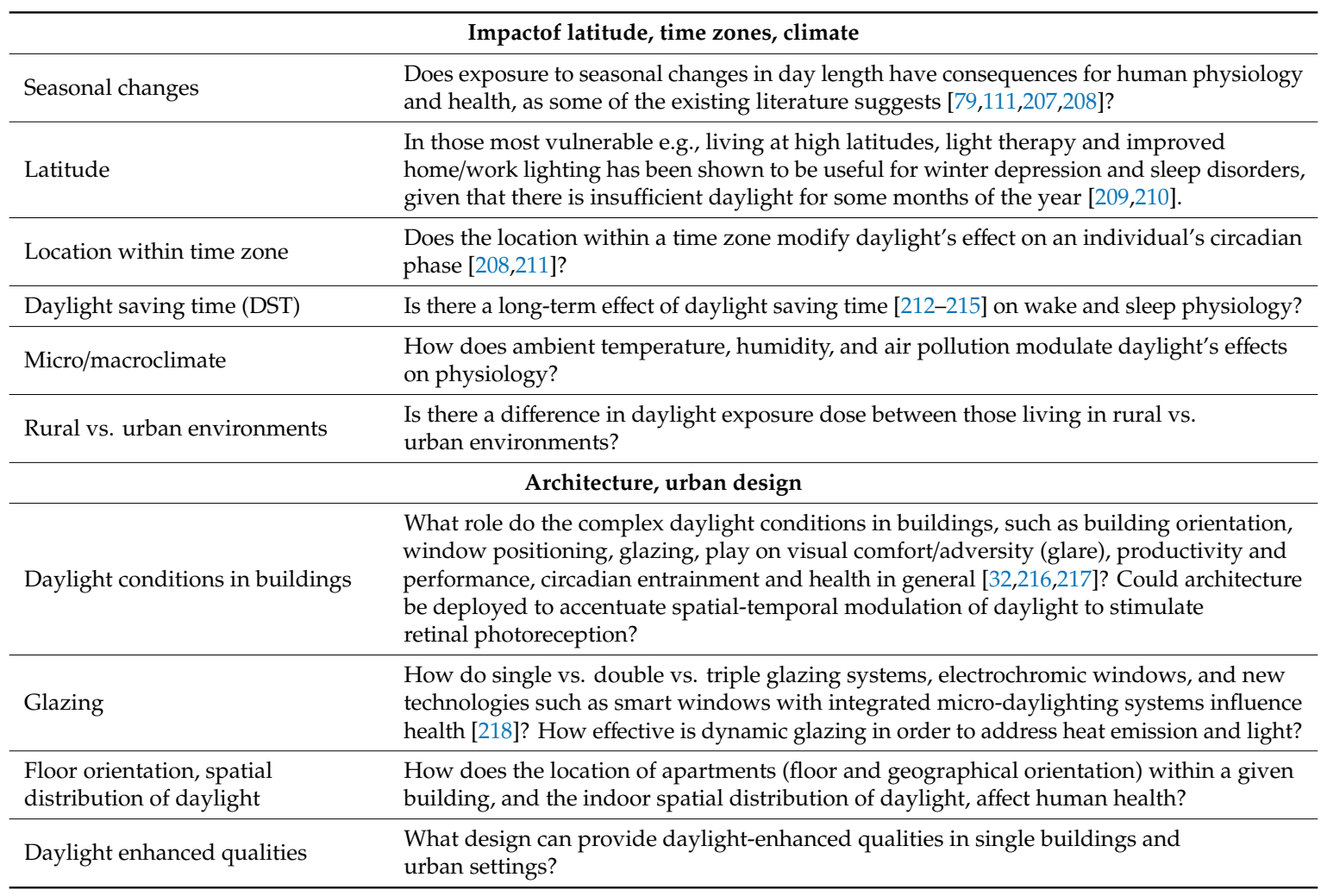


Table 6. Cont

\begin{tabular}{ll}
\hline $\begin{array}{l}\text { Complementation with electrical } \\
\text { light/daylight systems }\end{array}$ & $\begin{array}{l}\text { How can the geographical orientation of a building, which determines its indoor light } \\
\text { intensity, be compensated/complemented with daylight systems/electric light? }\end{array}$ \\
\hline (Day-) light control systems & $\begin{array}{l}\text { How should modern (light) sensor and controller technology be used to support health, } \\
\text { performance, and well-being of its inhabitants? }\end{array}$ \\
\hline Self-control of (day-) light & How much self-control over sensor control is necessary and desired [219]? \\
\hline Alienation from nature & $\begin{array}{l}\text { What are the consequences of losses of daylight/weather/seasonal effects due to urban } \\
\text { densification, loss of daylight recreation areas, daylight restriction due to high buildings } \\
\text { etc. on mood, health and quality of life [69,220-223]? }\end{array}$ \\
\hline Role of view & $\begin{array}{l}\text { Low daylight exposure and daylight deprivation usually also means deprivation from a } \\
\text { view. This could have additional and far-reaching negative consequences, although } \\
\text { research to date is scarce [223]. }\end{array}$ \\
\hline
\end{tabular}

\section{Gaps Group II: Lack of Consensus on Practical Measurement and Assessment Methods and Tools for Monitoring Real (Day-) Light Exposure Across Multiple Time Scales}

This crucial group of gaps describes the lack of appropriate methods in basic and applied (day)-light research. Many of these gaps apply generally to lighting research. The most important of these gaps are summarised in Table 7.

Table 7. Gaps in knowledge related to measurement tools and methods.

\begin{tabular}{|c|c|}
\hline $\begin{array}{l}\text { Automated integration of daylight } \\
\text { and electric light in buildings }\end{array}$ & $\begin{array}{l}\text { Lack of sophisticated and automated integration of daylight and electric light in buildings } \\
\text { and algorithms to detect the two separately (this would also support reduction of lighting } \\
\text { derived energy costs) }\end{array}$ \\
\hline $\begin{array}{l}\text { Tools for circadian phase } \\
\text { assessments }\end{array}$ & $\begin{array}{l}\text { Lack of practical means to make circadian phase assessments in daily life, the clinic, and } \\
\text { elsewhere (comparing electric and daylight conditions). }\end{array}$ \\
\hline Tools for mental health evaluations & $\begin{array}{l}\text { Long-term daily mental health evaluations; approaches developed so far are wrist-worn } \\
\text { diaries with visual analogue scales (also via mobile derived apps). }\end{array}$ \\
\hline $\begin{array}{l}\text { Standard operation procedures for } \\
\text { the use of daylight treatment and } \\
\text { daylight exposure (with regards to } \\
\text { non-visual light responses) }\end{array}$ & $\begin{array}{l}\text { Lack of standard operation procedures (SOPs) and definitions of daylight treatment } \\
\text { responses for different individuals and patients. There is a need for large-scale field studies } \\
\text { in schools, institutions (e.g., hospitals, prisons, care homes), shift- and non-shift } \\
\text { workplaces, people working underground and people frequently traveling across times } \\
\text { zones (with different overlay stays) using the same SOPs. }\end{array}$ \\
\hline Large scale lighting digitalisation & $\begin{array}{l}\text { Lack of large scale/practical biomedical digital techniques to design, monitor, predict and } \\
\text { validate individually tailored daylight exposure/electric light regimens. }\end{array}$ \\
\hline
\end{tabular}

\section{Gaps Group III: Insufficient Integration and Exchange of Daylight Knowledge Bases from Different Disciplines}

The impact of daylight depends on many "human" factors but is also determined by environmental and technical aspects and interacts with a variety of drivers and constraints at different levels and dimensions (see Figure 2). As such, daylight research cannot be comprehensively done exclusively within a single research community; it must involve many disciplines. A fundamental key gap is related to insufficient transdisciplinary approaches, with greater participation of a broader range of experts from different disciplines such as physicists (simulation modelling), ecologists, landscape architects (ecological laws), engineers (glazing, building principles), biomedical disciplines (health), biologists and psychologists (physiology and behaviour), artists, media/journalists, social scientists (social-ecology 
connectedness), architects and economists, to be able to find solutions for the connectedness between daylight/nature/living space/humans.

Access to natural daylight is nowadays unfortunately not considered as an explicit aim by leading institutions worldwide, such as, for example, the WHO, where the "Healthy Cities" concept, although it mentions access to green spaces, does not explicitly require access to daylight [226]. Accessibility to daylight should be part of global discussions about sustainable living, health and well-being, and should be included in the UN 2030 Agenda for Sustainable Development and the WHO's "health for all" policy [227].

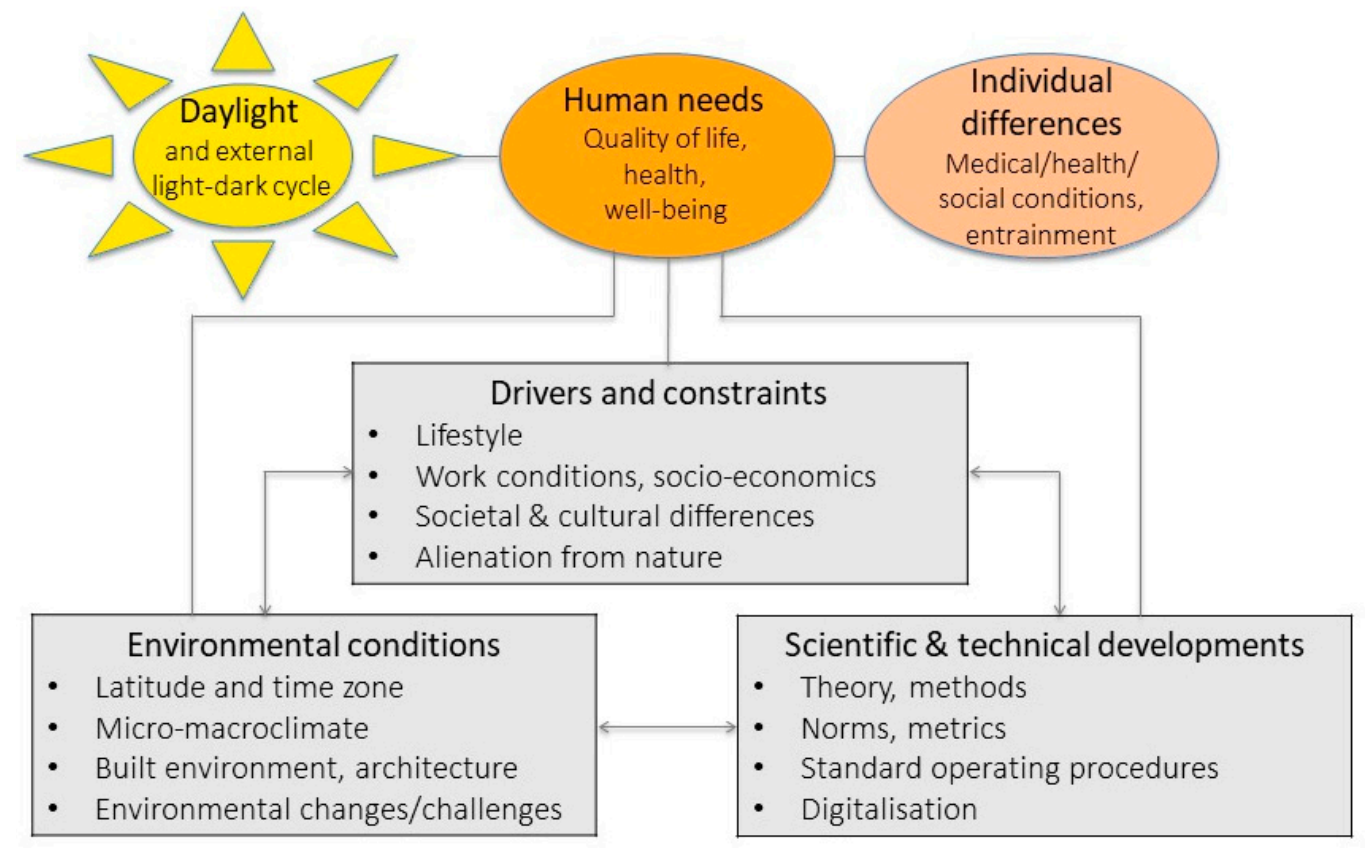

Figure 2. Illustration of daylight and other factors as determinants of human health. There are two main dimensions at the individual level, which are impacted by daylight: human needs and individual differences. There are three dimensions of reciprocal actions that modify the impact of daylight on humans: (1) drivers and constraints, (2) environmental conditions and (3) scientific and technical developments.

\section{What Is Needed to Fill These Gaps and Achieve the Goals in Daylight Research?}

The need to develop new tools, methods and approaches seems crucial, and here we highlight some possibilities. Tables 8 and 9 summarise the short- and long-term objectives in daylight research, respectively. 
Table 8. Short-term objectives in daylight research.

\begin{tabular}{ll}
\hline Criteria & $\begin{array}{l}\text { Define criteria for (day) light measures (see e.g., the new CIE standard S026). Universally agree } \\
\text { to use this new standard, which is facilitated by the CIE-S-026-EDI-Toolbox-beta version } \\
\text { E1.051.xls based on Ref. [228] and a more recent Tutorial [224]. }\end{array}$ \\
\hline $\begin{array}{l}\text { Daytime biomarkers for } \\
\text { physiology and behaviour }\end{array}$ & $\begin{array}{l}\text { Replicate physiological, cognitive and emotional outcome (bio-) markers, and validate more } \\
\text { than once in different laboratories, in order that they be implemented as reliable markers for } \\
\text { describing the effect of daylight on physiology and behaviour. }\end{array}$ \\
\hline Devices to monitor daylight & $\begin{array}{l}\text { Develop robust, validated and commercially affordable devices to monitor spectral daylight } \\
\text { exposure (representing light exposure at eye level in a vertical direction) along with } \\
\text { temperature and humidity continuously indoors and outdoors. The need to calibrate and } \\
\text { correct outputs from light recordings has been shown mostly for wrist worn devices [229,230]. }\end{array}$ \\
\hline $\begin{array}{l}\text { Application in different } \\
\text { populations }\end{array}$ & $\begin{array}{l}\text { The questions discussed in Sections 2 and 3 additionally need to be carried out in men and } \\
\text { women, different ages (children, elderly) and ethnic groups, monitored across different } \\
\text { environments (school/workplace/home); seasons; as well as in different patient groups (such as } \\
\text { disorders of the nervous system, eyes). }\end{array}$ \\
\hline Standard/exemplary data sets & $\begin{array}{l}\text { Collect and evaluate different data sets to assess how much and which qualities of daylight } \\
\text { different groups of individuals/patients receive at their work- and living places (24/7). }\end{array}$ \\
\hline Status quo in real life & $\begin{array}{l}\text { Define the status quo in daylight: irradiance measurements (including melanopic irradiance), } \\
\text { interviews/focus groups with target populations (e.g., care home residents, prison inmates, } \\
\text { dermatologists, ophthalmologists, shift- and night workers, tourist industry, people working } \\
\text { underground (at e.g., train stations, miners), and related disciplines. }\end{array}$ \\
\hline
\end{tabular}

Table 9. Long-term objectives in daylight research.

\begin{tabular}{|c|c|}
\hline Laboratory and field studies & $\begin{array}{l}\text { Do prospective longitudinal and multicentre studies using the established SOPs under } \\
\text { field and laboratory conditions in a sufficiently large sample, performed in both males } \\
\text { and females. }\end{array}$ \\
\hline $\begin{array}{l}\text { Combined day- and electric light } \\
\text { interventions }\end{array}$ & $\begin{array}{l}\text { Compare light interventions with daylight exposure, and not only electric light OR } \\
\text { daylight but also the (dynamic) mixture of both should be studied, since this is the norm. } \\
\text { Additionally, a suitable scheduled length of daily light exposure (daily accumulation) } \\
\text { requires monitoring over a long duration (chronic/seasonal light exposure). }\end{array}$ \\
\hline $\begin{array}{l}\text { Guidelines/recommendations } \\
\text { for research and clinical studies }\end{array}$ & $\begin{array}{l}\text { Propose guidelines/recommendations on how to set-up daylight research studies and } \\
\text { clinical trials with daylight interventions. }\end{array}$ \\
\hline $\begin{array}{l}\text { Guidelines/recommendations } \\
\text { for short- and long-term } \\
\text { interventions }\end{array}$ & $\begin{array}{l}\text { Propose guidelines/recommendations on how to measure/monitor daylight interventions } \\
\text { and related physiological and behavioural outcomes over time. }\end{array}$ \\
\hline $\begin{array}{l}\text { Tools for inter-individual } \\
\text { differences } \\
\text { and circadian phase }\end{array}$ & $\begin{array}{l}\text { Develop reliable tools to assess inter-individual differences and internal circadian phase for } \\
\text { users and practitioners. }\end{array}$ \\
\hline $\begin{array}{l}\text { Instruments for light monitoring } \\
\text { in the field }\end{array}$ & $\begin{array}{l}\text { Further validate instruments which monitor individual light and colour } \\
\text { perception/preferences under daylight conditions in the field. }\end{array}$ \\
\hline $\begin{array}{l}\text { Daylight recommendations for task } \\
\text { and biological requirements }\end{array}$ & $\begin{array}{l}\text { Develop daylight recommendations, which relate to both task requirements and } \\
\text { physiological/psychological aspects. }\end{array}$ \\
\hline Education & $\begin{array}{l}\text { Educate professionals, government policy makers, and the public in 'light hygiene' e.g., } \\
\text { sufficient vs. inadequate vs. too much daylight exposure. }\end{array}$ \\
\hline Architecture/building science & $\begin{array}{l}\text { Early stage planning of building/window positioning optimised for better daylight } \\
\text { exposure and spatial-temporal modulation. Develop real mixed electric light/daylight } \\
\text { simulation tools. Multimodal approach for optimised light exposure, heat emission, noise, } \\
\text { air quality. }\end{array}$ \\
\hline Database & Create an open access daylight database (wiki/online depository). \\
\hline Modelling & $\begin{array}{l}\text { Develop mathematical models that help predict biologically appropriate daylight exposure } \\
\text { (e.g., characteristics such as timing, dose, spectral composition and light exposure pattern) } \\
\text { for promoting circadian entrainment, sleep, performance and health in addition to the } \\
\text { required standards for visual function at the level of the individual as well as in } \\
\text { different populations. }\end{array}$ \\
\hline
\end{tabular}

\section{Summary}

Daylight research is much more complex and less controllable in the field than pure electric light research in the laboratory, and thus scientific methods and tools need to be developed to make daylight research accessible and studies comparable. Even more important is agreeing on methodology (SOPs) and running collaborative projects to provide large data sets. 


\section{Highlights}

- Recognising the importance of daylight for human health and well-being.

- Daylight research needs to define requirements for optimal physiological and psychological functioning.

- New techniques are required to monitor and assess (day-) light exposure in the field.

- Interdisciplinary exchange of daylight knowledge is the key to integrating findings into practice, whether architectural or medical.

Author Contributions: M.M., A.W.-J. and D.J.S. drafted the manuscript and all co-authors (S.A.B., T.K., K.M., O.S., C.V., K.P.W.J., K.W.) commented and edited the text. All authors have read and agreed to the published version of the manuscript.

Funding: The workshops were supported by the Daylight Academy (https://daylight.academy/).

Acknowledgments: We thank Christian Cajochen, Manuel Spitschan and Daniel Hulliger for their helpful comments on earlier versions of the manuscript.

Conflicts of Interest: The authors declared no potential conflicts of interest with respect to the authorship, and/or publication of this article. None of the authors had received monetary payments or gifts other than reimbursement of costs related to workshops' participation. None of the authors is an employee of the Daylight Academy or the Velux Stiftung Switzerland, or is in any kind related to the VELUX ${ }^{\circledR}$ company. The Daylight Academy is a spin-off of the Velux Stiftung Switzerland. The Velux Stiftung Switzerland is a registered non-profit organization (see https://veluxstiftung.ch/) and its members had at no time influence on the content of this manuscript. M.M., A.W.-J, S.A.B., K.M., K.W. have otherwise no conflict of interest to declare; T.K. is founder of SynOpus, a business involved in consulting to companies with respect to work design and lighting; O.S. is listed as an inventor on the following patents: US8646939B2-Display system having circadian effect on humans. DE102010047207B4-Projection system and method for projecting image content. US8994292B2-Adaptive lighting system. WO2006013041A1—Projection device and filter therefor. WO2016092112A1—Method for the selective adjustment of a desired brightness and/or color of a specific spatial area, and data processing device therefor. O.S. has had the following commercial interests related to lighting: Investigator-initiated research grants from Derungs, Audi, VW, Porsche, Festo, ZDF and Toshiba. Speaker fees for invited seminars from Firalux and Selux; C.V., during the conduct of the study, received research support from the NIH, was a honorary (unpaid) scientific advisory board member of Circadian Light Therapy Inc., and served as a paid consultant to the US Department of Energy outside the submitted work; K.P.W.J., during the conduct of the study, was a scientific advisory board member of and received personal fees from Torvec and received personal fees from Circadian Therapeutics, Inc. and from Kellogg Company; K.P.W.J. received research support from the NIH, the Office of Naval Research, the PAC-12 conference, and Somalogic, Inc. outside the submitted work; D.J.S. is co-inventor on two light patents (EP 1614441A1 and EP3055022A).

\section{References}

1. Zehring, W.; Wheeler, D.; Reddy, P.; Konopka, R.; Kyriacou, C.P.; Rosbash, M.; Hall, J. P-element transformation with period locus DNA restores rhythmicity to mutant, arrhythmic Drosophila melanogaster. Cell 1984, 39, 369-376. [CrossRef]

2. Bargiello, T.; Jackson, F.; Young, M. Restoration of circadian behavioural rhythms by gene transfer in Drosophila. Nature 1984, 312, 752-754. [CrossRef] [PubMed]

3. Vitaterna, M.; King, D.; Chang, A.-M.; Kornhauser, J.; Lowrey, P.; McDonald, J.; Dove, W.; Pinto, L.; Turek, F.; Takahashi, J. Mutagenesis and mapping of a mouse gene, clock, essential for circadian behavior. Science 1994, 264, 719-725. [CrossRef] [PubMed]

4. Shichida, Y.; Matsuyama, T. Evolution of opsins and phototransduction. Philos. Trans. R. Soc. Lond. B Biol. Sci. 2009, 364, 2881-2895. [CrossRef]

5. Nilsson, D. Eye evolution and its functional basis. Vis. Neurosci. 2013, 30, 5-20. [CrossRef]

6. Bellingham, J.; Foster, R.G. Opsins and mammalian photoentrainment. Cell Tissue Res. 2002, 309, 57-71. [CrossRef]

7. Koyanagi, M.; Kubokawa, K.; Tsukamoto, H.; Shichida, Y.; Terakita, A. Cephalochordate melanopsin: Evolutionary linkage between invertebrate visual cells and vertebrate photosensitive retinal ganglion cells. Curr. Biol. 2005, 15, 1065-1069. [CrossRef]

8. Peirson, S.; Halford, S.; Foster, R. The evolution of irradiance detection: Melanopsin and the non-visual opsins. Philos. Trans. R. Soc. Lond. B Biol. Sci. 2009, 364, 2849-2865. [CrossRef] 
9. Provencio, I.; Jiang, G.; De Grip, W.J.; Hayes, W.P.; Rollag, M.D. Melanopsin: An opsin in melanophores, brain, and eye. Proc. Natl. Acad. Sci. USA 1998, 95, 340-345. [CrossRef]

10. Hattar, S.; Liao, H.; Takao, M.; Berson, D.; Yau, K. Melanopsin-containing retinal ganglion cells: Architecture, projections, and intrinsic photosensitivity. Science 2002, 295, 1065-1070. [CrossRef]

11. Berson, D.M.; Dunn, F.A.; Takao, M. Phototransduction by retinal ganglion cells that set the circadian clock. Science 2002, 295, 1070-1073. [CrossRef] [PubMed]

12. Ruby, N.; Brennan, T.; Xie, X.; Cao, V.; Franken, P.; Heller, H.; O’Hara, B. Role of melanopsin in circadian responses to light. Science 2002, 298, 2211-2213. [CrossRef] [PubMed]

13. Provencio, I.; Rodriguez, I.R.; Jiang, G.; Hayes, W.P.; Moreira, E.F.; Rollag, M.D. A novel human opsin in the inner retina. J. Neurosci. 2000, 20, 600-605. [CrossRef] [PubMed]

14. Davies, T.; Smyth, T. Why artificial light at night should be a focus for global change research in the $21 \mathrm{st}$ century. Glob. Chang. Biol. 2018, 24, 872-882. [CrossRef]

15. Aschoff, J.; Wever, J. The Circadian System of Man. In Biological Rhythms; Aschoff, J., Ed.; Springer: Boston, MA, USA, 1981; pp. 311-331.

16. Pittendrigh, C.S. Circadian Systems: Entrainment. In Biological Rhythms; Aschoff, J., Ed.; Springer: Boston, MA, USA, 1981; pp. 95-124.

17. Roenneberg, T.; Daan, S.; Merrow, M. The art of entrainment. J. Biol. Rhythm. 2003, 18, 183-194. [CrossRef]

18. Vetter, C. Circadian disruption: What do we actually mean? Eur. J. Neurosci. 2018, 51, 531-550. [CrossRef]

19. Abbott, S.; Malkani, R.; Zee, P. Circadian disruption and human health: A bidirectional relationship. Eur. J. Neurosci. 2018, 51, 567-583. [CrossRef]

20. Zimmet, P.; Alberti, K.; Stern, N.; Bilu, C.; El-Osta, A.; Einat, H.; Kronfeld-Schor, N. The circadian syndrome: Is the metabolic syndrome and much more! J. Intern. Med. 2019, 286, 181-191. [CrossRef]

21. Logan, R.; McClung, C. Rhythms of life: Circadian disruption and brain disorders across the lifespan. Nat. Rev. Neurosci. 2019, 20, 49-65. [CrossRef]

22. Masri, S.; Sassone-Corsi, P. The emerging link between cancer, metabolism, and circadian rhythms. Nat. Med. 2018, 24, 1795-1803. [CrossRef]

23. Kervezee, L.; Kosmadopoulos, A.; Boivin, D. Metabolic and cardiovascular consequences of shift work: The role of circadian disruption and sleep disturbances. Eur. J. Neurosci 2018, 51, 396-412. [CrossRef] [PubMed]

24. McHill, A.; Wright, K.J. Role of sleep and circadian disruption on energy expenditure and in metabolic predisposition to human obesity and metabolic disease. Obes Rev. 2017, 18, 15-24. [CrossRef] [PubMed]

25. Eckel, R.H.; Depner, C.; Perreault, L.; Markwald, R.; Smith, M.; McHill, A.; Higgins, J.; Melanson, E.; Wright, K.J. Morning circadian misalignment during short sleep duration impacts insulin sensitivity. Curr. Biol. 2015, 25, 3004-3010. [CrossRef] [PubMed]

26. Depner, C.; Melanson, E.; Eckel, R.; Snell-Bergeon, J.; Perreault, L.; Bergman, B.; Higgins, J.; Guerin, M.; Stothard, E.; Morton, S.; et al. Ad libitum weekend recovery sleep fails to prevent metabolic dysregulation during a repeating pattern of insufficient sleep and weekend recovery sleep. Curr. Biol. 2019, 29, 957-967. [CrossRef] [PubMed]

27. Foster, R.G.; Wulff, K. The rhythm of rest and excess. Nat. Rev. Neurosci. 2005, 6, 407-414. [CrossRef]

28. Rijo-Ferreira, F.; Takahashi, J. Genomics of circadian rhythms in health and disease. Genome Med. 2019, 11, 82. [CrossRef]

29. Cederroth, C.; Albrecht, U.; Bass, J.; Brown, S.; Dyhrfjeld-Johnsen, J.; Gachon, F.; Green, C.; Hastings, M.; Helfrich-Forster, C.; Hogenesch, J.; et al. Medicine in the fourth dimension. Cell Metab. 2019, 30, 238-250. [CrossRef]

30. Solt, J. Changing perspectives on daylight: Science, technology and culture. In Sponsored Supplement to Science/AAS; Science/AAAS Custom Publishing Office: Washington, DC, USA, 2017; pp. 1-45.

31. Walker, W.; Melendez-Fernandez, O.; Nelson, R.; Reiter, R. Global climate change and invariable photoperiods: A mismatch that jeopardizes animal fitness. Ecol. Evol. 2019, 9, 10044-10054. [CrossRef]

32. Knoop, M.; Stefani, O.; Bueno, B.; Matusiak, B.; Hobday, R.; Wirz-Justice, A.; Martiny, K.; Kantermann, T.; Aarts, M.; Zemmouri, N.; et al. Daylight: What makes the difference? Lighting Res. Technol. 2019. [CrossRef]

33. Bartley, S.; Ball, R. Effects of intermittent photic input on brightness, hue, saturation, visual acuity, and stereopsis. Am. J. Optom. Arch. Am. Acad. Optom. 1969, 46, 315-318. [CrossRef]

34. Guth, S.; Eastman, A. Brightness difference in seeing. Am. J. Optom. Arch. Am. Acad. Optom. 1954, 31, 567-577. [CrossRef] [PubMed] 
35. Nelson, J. Ideal seeing conditions; the study of the human visual system as a basis for prescribing lighting. Br. Ind. Med. 1945, 2, 224-232. [CrossRef] [PubMed]

36. Hunt, R. The effects of daylight and tungsten light-adaptation on color perception. J. Opt. Soc. Am. 1950, 40, 362-371. [CrossRef]

37. Luckiesh, M. A note on color preference. Am. J. Psychol. 1916, 27, 251-255. [CrossRef]

38. Boyce, P. Human Factors in Lighting, 2nd ed.; CRC Press: London, UK; New York, NY, USA, 2003.

39. Hopkinson, R. Glare from daylighting in buildings. Appl. Ergonom. 1972, 3, 206-215. [CrossRef]

40. Borisuit, A.; Linhart, F.; Scartezzini, J.-L.; Münch, M. Effects of realistic office day- and electric lighting conditions on visual comfort, alertness and mood. Lighting Res. Technol. 2014, 47, 192-209. [CrossRef]

41. Pierson, C.; Wienold, J.; Bodart, M. Review of factors influencing discomfort glare perception from daylight. Leukos 2018, 14, 111-148. [CrossRef]

42. Veitch, J.; Newsham, G.; Boyce, P.; Jones, C. Lighting appraisal, well-being, and performance in open-plan offices: A linked mechansisms approach. Lighting Res. Technol. 2008, 40, 133-151. [CrossRef]

43. Chinazzo, G.; Wienold, J.; Andersen, M. Daylight affects human thermal perception. Sci. Rep. 2019, 9, 13690. [CrossRef]

44. Te Kulve, M.; Schlangen, L.; van Marken Lichtenbelt, W. Interactions between the perception of light and temperature. Indoor Air 2018, 28, 881-891. [CrossRef]

45. Cajochen, C.; Münch, M.; Kobialka, S.; Kräuchi, K.; Steiner, R.; Oelhafen, P.; Orgül, S.; Wirz-Justice, A. High sensitivity of human melatonin, alertness, thermoregulation and heart rate to short wavelength light. J. Clin. Endocrinol. Metab. 2005, 90, 1311-1316. [CrossRef] [PubMed]

46. Lockley, S.W.; Evans, E.E.; Scheer, F.A.J.L.; Brainard, G.C.; Czeisler, C.A.; Aeschbach, D. Short-wavelength sensitivity for the direct effects of light on alertness, vigilance, and the waking electroencephalogram in humans. Sleep 2006, 29, 161-168. [PubMed]

47. Revell, V.; Skene, D. Light-induced melatonin suppression in humans with polychromatic and monochromatic light. Chronobiol. Int. 2007, 24, 1125-1137. [CrossRef] [PubMed]

48. Rahman, S.; Flynn-Evans, E.; Aeschbach, D.; Brainard, G.; Czeisler, C.; Lockley, S. Diurnal spectral sensitivity of the acute alerting effects of light. Sleep 2014, 37, 271-281. [CrossRef] [PubMed]

49. Souman, J.; Tinga, A.; te Pas, S.; van Ee, R.; Vlaskamp, B. Acute alerting effects of light: A systematic literature review. Behav. Brain Res. 2018, 337, 228-239. [CrossRef] [PubMed]

50. Cajochen, C.; Jud, C.; Münch, M.; Kobialka, S.; Wirz-Justice, A.; Albrecht, U. Evening exposure to blue light stimulates the expression of the clock gene PER2 in humans. Eur. J. Neurosci. 2006, 23, 1082-1086. [CrossRef] [PubMed]

51. Santhi, N.; Groeger, J.; Archer, S.; Gimenez, M.; Schlangen, L.; Dijk, D. Morning sleep inertia in alertness and performance: Effect of cognitive domain and white light conditions. PLoS ONE 2013, 8, e79688. [CrossRef]

52. Prayag, A.; Jost, S.; Avouac, P.; Dumortier, D.; Gronfier, C. Dynamics of non-visual responses in humans: As fast as lightning? Front. Neurosci. 2019, 13, 126. [CrossRef]

53. Vandewalle, G.; Maquet, P.; Dijk, D. Light as a modulator of cognitive brain function. Trends Cogn. Sci. 2009, 13, 429-438. [CrossRef]

54. Münch, M.; Scheuermaier, K.; Zhang, R.; Dunne, S.; Guzik, A.; Silva, E.J.; Ronda, J.; Duffy, J. Effects on subjective and objective alertness and sleep in response to evening light exposure in older subjects. Behav. Brain Res. 2011, 224, 272-278. [CrossRef]

55. Chellappa, S.L.; Steiner, R.; Blattner, P.; Oelhafen, P.; Götz, T.; Cajochen, C. Non-visual effects of light on melatonin, alertness and cognitive performance: Can blue-enriched light keep us alert? PLoS ONE 2011, 6, e16429. [CrossRef] [PubMed]

56. Rüger, M.; Gordijn, M.C.M.; Beersma, D.G.M.; de Vries, B.; Daan, S. Time-of-day-dependent effects of bright light exposure on human psychophysiology: Comparison of daytime and nighttime exposure. Am. J. Physiol. Regul. Integr. Comp. Physiol. 2006, 290, R1413-R1420. [CrossRef] [PubMed]

57. Jung, C.M.; Khalsa, S.B.S.; Scheer, F.A.J.L.; Cajochen, C.; Lockley, S.W.; Czeisler, C.A.; Wright, K. Acute effects of bright light exposure on cortisol levels. J. Biol. Rhythms 2010, 25, 208-216. [CrossRef] [PubMed]

58. Münch, M.; Kobialka, S.; Steiner, R.; Oelhafen, P.; Wirz-Justice, A.; Cajochen, C. Wavelength-dependent effects of evening light exposure on sleep architecture and sleep EEG power density in men. Am. J. Physiol. Regul. Integr. Comp. Physiol. 2006, 290, R1421-R1428. [CrossRef] [PubMed] 
59. Brainard, G.; Hanifin, J.; Greeson, J.; Byrne, B.; Glickman, G.; Gerner, E.; Rollag, M. Action spectrum for melatonin regulation in humans: Evidence for a novel circadian photoreceptor. J. Neurosci. 2001, 21, 6405-6412. [CrossRef]

60. Thapan, K.; Arendt, J.; Skene, D.J. An action spectrum for melatonin suppression: Evidence for a novel non-rod, non-cone photoreceptor system in humans. J. Physiol. London 2001, 535, 261-267. [CrossRef]

61. Gooley, J.; Rajaratnam, S.; Brainard, G.; Kronauer, R.; Czeisler, C.; Lockley, S. Spectral responses of the human circadian system depend on the irradiance and duration of exposure to light. Sci. Transl. Med. 2010, 2, 31 ra33. [CrossRef]

62. Zaidi, F.; Hull, J.; Peirson, S.; Wulff, K.; Aeschbach, D.; Gooley, J.; Brainard, G.; Gregory-Evans, K.; Rizzo Iii, J.; Czeisler, C.; et al. Short-wavelength light sensitivity of circadian, pupillary, and visual awareness in humans lacking an outer retina. Curr. Biol. 2007, 17, 2122-2128. [CrossRef]

63. Boubekri, M.; Cheung, I.N.; Reid, K.; Wang, C.; Zee, P. Impact of windows and daylight exposure on overall health and sleep quality of office workers: A case-control pilot study. J. Clin. Sleep Med. 2014, 10, 603-611. [CrossRef]

64. Figueiro, M.; Rea, M. Office lighting and personal light exposures in two seasons: Impact on sleep and mood. Lighting Res. Technol. 2016, 48, 352-364. [CrossRef]

65. Viola, A.U.; James, L.; Schlangen, L.; Dijk, D. Blue-enriched white light in the workplace improves self-reported alertness, performance and sleep quality. Scand. J. Work Environ. Health 2008, 34, 297-306. [CrossRef] [PubMed]

66. Vetter, C.; Juda, M.; Lang, D.; Wojtysiak, A.; Roenneberg, T. Blue-enriched office light competes with natural light as a zeitgeber. Scand J. Work Environ. Health 2011, 34, 297-306. [CrossRef] [PubMed]

67. Maierova, L.; Borisuit, A.; Scartezzini, J.-L.; Jaeggi, S.; Schmidt, C.; Munch, M. Diurnal variations of hormonal secretion, alertness and cognition in extreme chronotypes under different lighting conditions. Sci. Rep. 2016, 6. [CrossRef] [PubMed]

68. Begeman, S.; Beld, G.; Tenner, A. Daylight, artificial light and people in an office environment, overview of visual and biological responses. Int. J. Ind. Ergon. 1997, 20, 231-239. [CrossRef]

69. Beute, F.; de Kort, Y. The natural context of wellbeing: Ecological momentary assessment of the influence of nature and daylight on affect and stress for individuals with depression levels varying from none to clinical. Health Place 2018, 49, 7-18. [CrossRef] [PubMed]

70. Veitch, J.; Bisegna, F.; Hubalek, S.; Knoop, M.; Koga, Y.; Noguchi, H.; Schierz, C.; Thorns, P.; Vries, A. Research Roadmap for Healthful Interior Lighting Applications; CIE: Vienna, Austria, 2016.

71. Heschong, L. Daylighting and human performance. ASHRAE J. 2002, 44, 65-67.

72. Cheung, I.; Zee, P.; Shalman, D.; Malkani, R.; Kang, J.; Reid, K. Morning and evening blue-enriched light exposure alters metabolic function in normal weight adults. PLoS ONE 2016, 11, e0155601. [CrossRef]

73. Melanson, E.; Ritchie, H.; Dear, T.; Catenacci, V.; Shea, K.; Connick, E.; Moehlman, T.; Stothard, E.; Higgins, J.; McHill, A.; et al. Daytime bright light exposure, metabolism, and individual differences in wake and sleep energy expenditure during circadian entrainment and misalignment. Neurobiol. Sleep Circadian Rhythm. 2018, 4, 49-56. [CrossRef]

74. Danilenko, K.; Mustafina, S.; Pechenkina, E. Bright light for weight loss: Results of a controlled crossover trial. Obes Facts 2013, 6, 28-38. [CrossRef]

75. Wams, E.; Woelders, T.; Marring, I.; van Rosmalen, L.; Beersma, D.; Gordijn, M.; Hut, R. Linking light exposure and subsequent sleep: A field polysomnography study in humans. Sleep 2017, 40. [CrossRef]

76. Cajochen, C.; Freyburger, M.; Basishvili, T.; Garbazza, C.; Rudzik, F.; Renz, C.; Kobayashi, K.; Shirakawa, Y.; Stefani, O.; Weibel, J. Effect of daylight LED on visual comfort, melatonin, mood, waking performance and sleep. Lighting Res. Technol. 2019. [CrossRef]

77. Cajochen, C.; Reichert, C.; Maire, M.; Schlangen, L.; Schmidt, C.; Viola, A.; Gabel, V. Evidence that homeostatic sleep regulation depends on ambient lighting conditions during wakefulness. Clocks Sleep 2019, 1, 517-531. [CrossRef]

78. Wright, K., Jr.; McHill, A.; Birks, B.; Griffin, B.; Rusterholz, T.; Chinoy, E. Entrainment of the human circadian clock to the natural light-dark cycle. Curr. Biol. 2013, 23, 1554-1558. [CrossRef] [PubMed]

79. Stothard, E.; McHill, A.; Depner, C.; Birks, B.; Moehlman, T.; Ritchie, H.; Guzzetti, J.; Chinoy, E.; LeBourgeois, M.; Axelsson, J.; et al. Circadian entrainment to the natural light-dark cycle across seasons and the weekend. Curr. Biol. 2017, 27, 508-513. [CrossRef] 
80. Münch, M.; Nowozin, C.; Regente, J.; Bes, F.; De Zeeuw, J.; Hadel, S.; Wahnschaffe, A.; Kunz, D. Blue-enriched morning light as a countermeasure to light at the wrong time: Effects on cognition, sleepiness, sleep, and circadian phase. Neuropsychobiology 2016, 74, 207-218. [CrossRef]

81. Cajochen, C.; Zeitzer, J.M.; Czeisler, C.A.; Dijk, D. Dose-response relationship for light intensity and alertness and its ocular and EEG correlates. Sleep Res. Onl. 1999, 2, 517.

82. Smolders, K.; Peeters, S.; Vogels, I.; de Kort, Y. Investigation of dose-response relationships for effects of white light exposure on correlates of alertness and executive control during regular daytime working hours. J. Biol. Rhythm. 2018, 33, 649-661. [CrossRef]

83. Sahin, L.; Wood, B.; Plitnick, B.; Figueiro, M. Daytime light exposure: Effects on biomarkers, measures of alertness, and performance. Behav. Brain Res. 2014, 274, 176-185. [CrossRef]

84. Allen, A.; Hazelhoff, E.; Martial, F.; Cajochen, C.; Lucas, R. Exploiting metamerism to regulate the impact of a visual display on alertness and melatonin suppression independent of visual appearance. Sleep 2018, 41, zsy100. [CrossRef]

85. Rahman, S.A.; St Hilaire, M.A.; Lockley, S. The effects of spectral tuning of evening ambient light on melatonin suppression, alertness and sleep. Physiol. Behav. 2017, 177, 221-229. [CrossRef]

86. De Zeeuw, J.; Papakonstantinou, A.; Nowozin, C.; Stotz, S.; Zaleska, M.; Hädel, S.; Bes, F.; Münch, M.; Kunz, D. Living in biological darkness: Objective sleepiness and the pupillary light responses are affected by different metameric lighting conditions during daytime. J. Biol. Rhythm. 2019, 34, 410-431. [CrossRef] [PubMed]

87. Youngstedt, S.; Elliott, J.; Kripke, D. Human circadian phase-response curves for exercise. J. Physiol. London 2019, 597, 2253-2268. [CrossRef] [PubMed]

88. Barger, L.; Wright, K.J.; Hughes, R.; Czeisler, C. Daily exercise facilitates phase delays of circadian melatonin rhythm in very dim light. Am. J. Physiol. Regul. Integr. Comp. Physiol. 2004, 286, R1077-R1084. [CrossRef] [PubMed]

89. Knaier, R.; Meister, S.; Aeschbacher, T.; Gemperle, D.; Rossmeissl, A.; Cajochen, C.; Schmidt-Trucksass, A. Dose-response relationship between light exposure and cycling performance. Scand. J. Med. Sci. Sports 2016, 26, 794-801. [CrossRef]

90. Aschoff, J.; Wever, R. Spontanperiodik des Menschen bei Auschluss aller Zeitgeber. Die Naturwissenschaften 1962, 49, 337-342. [CrossRef]

91. Gronfier, C.; Wright, K.P., Jr.; Kronauer, R.E.; Czeisler, C.A. Entrainment of the human circadian pacemaker to longer-than-24-h days. Proc. Natl. Acad. Sci. USA 2007, 104, 9081-9086. [CrossRef]

92. Wright, K.P., Jr.; Hughes, R.J.; Kronauer, R.E.; Dijk, D.J.; Czeisler, C.A. Intrinsic near-24-h pacemaker period determines limits of circadian entrainment to a weak synchronizer in humans. Proc. Natl. Acad. Sci. USA 2001, 98, 14027-14032. [CrossRef]

93. Boivin, D.B.; Duffy, J.F.; Kronauer, R.E.; Czeisler, C.A. Dose-response relationships for resetting of human circadian clock by light. Nature 1996, 379, 540-542. [CrossRef]

94. Scheer, F.A.; Wright, K.P., Jr.; Kronauer, R.E.; Czeisler, C.A. Plasticity of the intrinsic period of the human circadian timing system. PLoS ONE 2007, 2, e721. [CrossRef]

95. Eastman, C.; Miescke, K. Entrainment of circadian rhythms with 26-h bright light and sleep-wake schedules. Am J. Physiol. 1990, 259, R1189-R1197. [CrossRef]

96. Wever, R.A. The Circadian System of Man: Results of Experiments under Temporal Isolation; Springer: New York, NY, USA, 1979.

97. Czeisler, C.A.; Richardson, G.S.; Zimmerman, J.Z.; Moore-Ede, M.C.; Weitzman, E.D. Entrainment of human circadian rhythms by light-dark cycles: A reassessment. Photochem. Photobiol. 1981, 34, 239-247. [CrossRef] [PubMed]

98. Emens, J.S.; Yuhas, K.; Rough, J.; Kochar, N.; Peters, D.; Lewy, A. Phase angle of entrainment in morningand evening-types under naturalistic conditions. Chronobiol. Int. 2009, 26, 474-493. [CrossRef] [PubMed]

99. Moreno, C.; Vasconcelos, S.; Marqueze, E.; Lowden, A.; Middleton, B.; Fischer, F.; Louzada, F.; Skene, D. Sleep patterns in Amazon rubber tappers with and without electric light at home. Sci. Rep. 2015, 5, 14074. [CrossRef] [PubMed]

100. Woelders, T.; Wams, E.J.; Gordijn, M.; Beersma, D.; Hut, R. Integration of color and intensity increases time signal stability for the human circadian system when sunlight is obscured by clouds. Sci. Rep. 2018, 8, 15214. [CrossRef] 
101. Roenneberg, T.; Foster, R.G. Twilight times: Light and the circadian system. Photochem. Photobiol. 1997, 66, 549-561. [CrossRef]

102. Danilenko, K.V.; Wirz-Justice, A.; Kräuchi, K.; Weber, J.M.; Terman, M. The human circadian pacemaker can see by the dawn's early light. J. Biol. Rhythm. 2000, 15, 437-446. [CrossRef]

103. Walmsley, L.; Hanna, L.; Mouland, J.; Martial, F.; West, A.; Smedley, A.; Bechtold, D.; Webb, A.; Lucas, R.; Brown, T. Colour as a signal for entraining the mammalian circadian clock. PLoS Biol. 2015, 13, e1002127. [CrossRef]

104. Mouland, J.W.; Martial, F.; Watson, A.; Lucas, R.; Brown, T. Cones support alignment to an inconsistent world by suppressing mouse circadian responses to the blue colors associated with twilight. Curr. Biol. 2019, 29, 4260-4267. [CrossRef]

105. Brainard, G.; Rollag, M.; Hanifin, J.; van den Beld, G.; Sanford, B. The effect of polarized versus nonpolarized light on melatonin regulation in humans. Photochem. Photobiol. 2000, 71, 766-770. [CrossRef]

106. Dacey, D.; Liao, H.; Peterson, B.; Robinson, F.; Smith, V.; Pokorny, J.; Yau, K.; Gamlin, P. Melanopsin-expressing ganglion cells in primate retina signal colour and irradiance and project to the LGN. Nature 2005, 433, 749-754. [CrossRef]

107. Rüger, M.; Gordijn, M.C.M.; Beersma, D.G.M.; DeVries, B.; Daan, S. Nasal versus temporal illumination of the human retina: Effects on core body temperature, melatonin, and circadian phase. J. Biol. Rhythm. 2005, 20, 60-70. [CrossRef] [PubMed]

108. Visser, E.K.; Beersma, D.G.M.; Daan, S. Melatonin suppression by light in humans is maximal when the nasal part of the retina is illuminated. J. Biol. Rhythm. 1999, 14, 116-121. [CrossRef] [PubMed]

109. Glickman, G.; Hanifin, J.; Rollag, M.; Wang, J.; Cooper, H.; Brainard, G. Inferior retinal light exposure is more effective than superior retinal exposure in suppressing melatonin in humans. J. Biol. Rhythm. 2003, 18, 71-79. [CrossRef]

110. Cajochen, C.; Di Biase, R.; Imai, M. Interhemispheric EEG asymmetries during unilateral bright-light exposure and subsequent sleep in humans. Am. J. Physiol. Regul. Integr. Comp. Physiol. 2008, 294, R1053-R1060. [CrossRef] [PubMed]

111. Wehr, T.A. Effect of seasonal changes in daylength on human neuroendocrine function. Horm. Res. 1998, 49, 118-124. [CrossRef] [PubMed]

112. Rabstein, S.; Burek, K.; Lehnert, M.; Beine, A.; Vetter, C.; Harth, V.; Putzke, S.; Kantermann, T.; Walther, J.; Wang-Sattler, R.; et al. Differences in twenty-four-hour profiles of blue-light exposure between day and night shifts in female medical staff. Sci. Total Environ. 2019, 653, 1025-1033. [CrossRef]

113. Lowden, A.; Ozturk, G.; Reynolds, A.; Bjorvatn, B. Working Time society consensus statements: Evidence based interventions using light to improve circadian adaptation to working hours. Ind. Health 2019, 57, 213-227. [CrossRef]

114. Boivin, D.B.; Boudreau, P.; James, F.O.; Kin, N.M. Photic resetting in night-shift work: Impact on nurses' sleep. Chronobiol. Int. 2012, 29, 619-628. [CrossRef]

115. Nowozin, C.; Wahnschaffe, A.; Rodenbeck, A.; de Zeeuw, J.; Hadel, S.; Kozakov, R.; Schopp, H.; Munch, M.; Kunz, D. Applying melanopic lux to measure biological light effects on melatonin suppression and subjective sleepiness. Curr. Alzheimer Res. 2017, 14, 1042-1052. [CrossRef]

116. Lok, R.; Woelders, T.; Gordijn, M.; Hut, R.; Beersma, D.G. White light during daytime does not improve alertness in well-rested individuals. J. Biol. Rhythm. 2018, 33, 637-648. [CrossRef]

117. Mure, L.; Vinberg, F.; Hanneken, A.; Panda, S. Functional diversity of human intrinsically photosensitive retinal ganglion cells. Science 2019, 366, 1251-1255. [CrossRef] [PubMed]

118. Kaynezhad, P.; Tachtsidis, I.; Jeffery, G. Optical monitoring of retinal respiration in real time: $670 \mathrm{~nm}$ light increases the redox state of mitochondria. Exp. Eye Res. 2016, 152, 88-93. [CrossRef] [PubMed]

119. Sivapathasuntharam, C.; Sivaprasad, S.; Hogg, C.; Jeffery, G. Improving mitochondrial function significantly reduces the rate of age related photoreceptor loss. Exp. Eye Res. 2019, 185, 107691. [CrossRef] [PubMed]

120. Chang, A.; Santhi, N.; St Hilaire, M.; Gronfier, C.; Bradstreet, D.; Duffy, J.; Lockley, S.; Kronauer, R.; Czeisler, C. Human responses to bright light of different durations. J. Physiol. London 2012, 590, 3103-3112. [CrossRef] [PubMed]

121. Spitschan, M.; Bock, A.; Ryan, J.; Frazzetta, G.; Brainard, D.; Aguirre, G. The human visual cortex response to melanopsin-directed stimulation is accompanied by a distinct perceptual experience. Proc. Natl. Acad. Sci. USA 2017, 114, 12291-12296. [CrossRef] 
122. Faulkner, S.; Bee, P.; Meyer, N.; Dijk, D.; Drake, R. Light therapies to improve sleep in intrinsic circadian rhythm sleep disorders and neuro-psychiatric illness: A systematic review and meta-analysis. Sleep Med. Rev. 2019, 46, 108-123. [CrossRef]

123. Geoffroy, P.; Schroder, C.; Reynaud, E.; Bourgin, P. Efficacy of light therapy versus antidepressant drugs, and of the combination versus monotherapy, in major depressive episodes: A systematic review and meta-analysis. Sleep Med. Rev. 2019, 48, 101213. [CrossRef]

124. Gottlieb, J.; Benedetti, F.; Geoffroy, P.; Henriksen, T.; Lam, R.; Murray, G.; Phelps, J.; Sit, D.; Swartz, H.; Crowe, M.; et al. The chronotherapeutic treatment of bipolar disorders: A systematic review and practice recommendations from the ISBD task force on chronotherapy and chronobiology. Bipolar. Disord. 2019, 21, 741-773. [CrossRef]

125. Penders, T.; Stanciu, C.; Schoemann, A.; Ninan, P.; Bloch, R.; Saeed, S. Bright light therapy as augmentation of pharmacotherapy for treatment of depression: A systematic review and meta-analysis. Prim. Care Companion CNS Disord. 2016, 18. [CrossRef]

126. Beaulieu, C.; Rufiange, M.; Dumont, M.; Lachapelle, P. Modulation of ERG retinal sensitivity parameters with light environment and photoperiod. Doc. Ophthalmol. 2009, 118, 89-99. [CrossRef]

127. Danilenko, K.; Plisov, I.; Wirz-Justice, A.; Hebert, M. Human retinal light sensitivity and melatonin rhythms following four days in near darkness. Chronobiol. Int. 2009, 26, 93-107. [CrossRef] [PubMed]

128. Kawasaki, A.; Wisniewski, S.; Healey, B.; Pattyn, N.; Kunz, D.; Basner, M.; Munch, M. Impact of long-term daylight deprivation on retinal light sensitivity, circadian rhythms and sleep during the Antarctic winter. Sci. Rep. 2018, 8, 16185. [CrossRef] [PubMed]

129. Owen, J.; Arendt, J. Melatonin suppression in human subjects by bright and dim light in antarctica: Time and season-dependent effects. Neurosci. Lett. 1992, 137, 181-184. [CrossRef]

130. Jasser, S.A.; Hanifin, J.; Rollag, M.; Brainard, G. Dim light adaptation attenuates acute melatonin suppression in humans. J. Biol. Rhythm. 2006, 21, 394-404. [CrossRef] [PubMed]

131. Hébert, M.; Martin, S.K.; Eastman, C.I. The effects of prior light history on the suppression of melatonin by light in humans. J. Pineal Res. 2002, 33, 198-203. [CrossRef] [PubMed]

132. Chang, A.; Scheer, F.; Czeisler, C.; Aeschbach, D. Direct effects of light on alertness, vigilance, and the waking electroencephalogram in humans depend on prior light history. Sleep 2013, 36, 1239-1246. [CrossRef]

133. Chakraborty, R.; Ostrin, L.; Nickla, D.; Iuvone, P.; Pardue, M.; Stone, R. Circadian rhythms, refractive development, and myopia. Ophthalmic Physiol. Opt. 2018, 38, 217-245. [CrossRef]

134. Riemersma-van der Lek, R.F.; Swaab, D.F.; Twisk, J.; Hol, E.M.; Hoogendijk, W.J.G.; Van Someren, E.J.W. Effect of bright light and melatonin on cognitive and noncognitive function in elderly residents of group care facilities: A randomized controlled trial. JAMA 2008, 299, 2642-2655. [CrossRef]

135. Bromundt, V.; Wirz-Justice, A.; Boutellier, M.; Winter, S.; Haberstroh, M.; Terman, M.; Munch, M. Effects of a dawn-dusk simulation on circadian rest-activity cycles, sleep, mood and well-being in dementia patients. Exp. Gerontol. 2019, 124, 110641. [CrossRef]

136. Wahnschaffe, A.; Nowozin, C.; Haedel, S.; Rath, A.; Appelhof, S.; Munch, M.; Kunz, D. Implementation of dynamic lighting in a nursing home: Impact on agitation but not on rest-activity patterns. Curr. Alzheimer Res. 2017, 14, 1076-1083. [CrossRef]

137. Figueiro, M.; Plitnick, B.; Roohan, C.; Sahin, L.; Kalsher, M.; Rea, M. Effects of a tailored lighting intervention on sleep quality, rest-activity, mood, and behavior in older adults with Alzheimer disease and related dementias: A randomized clinical trial. Clin. Sleep Med. 2019, 15, 1757-1767. [CrossRef] [PubMed]

138. Figueiro, M.; Plitnick, B.; Lok, A.; Jones, G.; Higgins, P.; Hornick, T.; Rea, M.S. Tailored lighting intervention improves measures of sleep, depression, and agitation in persons with Alzheimer's disease and related dementia living in long-term care facilities. Clin. Interv. Aging 2014, 9, 1527-1537. [CrossRef] [PubMed]

139. Fargason, R.; Fobian, A.; Hablitz, L.; Paul, J.; White, B.; Cropsey, K.; Gamble, K. Correcting delayed circadian phase with bright light therapy predicts improvement in ADHD symptoms: A pilot study. J. Psychiatr. Res. 2017, 91, 105-110. [CrossRef] [PubMed]

140. Bromundt, V.; Wirz-Justice, A.; Kyburz, S.; Opwis, K.; Dammann, G.; Cajochen, C. Circadian sleep-wake cyles, well-being, and light therapy in borderline personality disorder. J. Pers. Disord. 2012, 27, 680-696. [CrossRef] [PubMed] 
141. Rutten, S.; Vriend, C.; van den Heuvel, O.; Smit, J.; Berendse, H.; van der Werf, Y. Bright light therapy in Parkinson's disease: An overview of the background and evidence. Parkinson's Dis. 2012, 2012, 767105. [CrossRef] [PubMed]

142. Smilowska, K.; van Wamelen, J.; Schoutens, A.; Meinders, M.; Bloem, B. Blue light therapy glasses in Parkinson's disease: patients' experience. Parkinson's Dis. 2019, 2019, 1906271. [CrossRef] [PubMed]

143. Burkhalter, H.; Wirz-Justice, A.; Denhaerynck, K.; Fehr, T.; Steiger, J.; Venzin, R.; Cajochen, C.; Weaver, T.; De Geest, S. The effect of bright light therapy on sleep and circadian rhythms in renal transplant recipients: A pilot randomized, multicentre wait-list controlled trial. Transpl. Int. 2015, 28, 59-70. [CrossRef]

144. Johnson, J.; Garland, S.; Carlson, L.; Savard, J.; Simpson, J.; Ancoli-Israel, S.; Campbell, T. Bright light therapy improves cancer-related fatigue in cancer survivors: A randomized controlled trial. J. Cancer Surviv. 2018, 12, 206-215. [CrossRef]

145. Wirz-Justice, A.; Graw, P.; Kräuchi, K.; Sarrafzadeh, A.; English, J.; Arendt, J.; Sand, L. Natural' light treatment of seasonal affective disorder. J. Affect. Disord. 1996, 37, 109-120. [CrossRef]

146. Gbyl, K.; Ostergaard Madsen, H.; Dunker Svendsen, S.; Petersen, P.; Hageman, I.; Volf, C.; Martiny, K. Depressed patients hospitalized in southeast-facing rooms are discharged earlier than patients in Northwest-facing rooms. Neuropsychobiology 2016, 74, 193-201. [CrossRef]

147. Gbyl, K.; Ostergaard Madsen, H.; Dunker Svendsen, S.; Petersen, P.; Hageman, I.; Volf, C.; Martiny, K. Erratum. Neuropsychobiology 2017, 75, 52. [CrossRef]

148. Benedetti, F.; Colombo, C.; Barbini, B.; Campori, E.; Smeraldi, E. Morning sunlight reduces length of hospitalization in bipolar depression. J. Affect. Disord. 2001, 62, 221-223. [CrossRef]

149. Gimenez, M.; Geerdinck, L.; Versteylen, M.; Leffers, P.; Meekes, G.; Herremans, H.; de Ruyter, B.; Bikker, J.; Kuijpers, P.; Schlangen, L. Patient room lighting influences on sleep, appraisal and mood in hospitalized people. J. Sleep Res. 2017, 26, 236-246. [CrossRef] [PubMed]

150. Luetz, A.; Grunow, J.; Morgeli, R.; Rosenthal, M.; Weber-Carstens, S.; Weiss, B.; Spies, C. Innovative ICU solutions to prevent and reduce delirium and post-intensive care unit syndrome. Semin. Respir. Crit. Care Med. 2019, 40, 673-686. [CrossRef]

151. Beauchemin, K.M.; Hays, P. Dying in the dark: Sunshine, gender and outcomes in myocardial infarction. J. R. Soc. Med. 1998, 91, 352-354. [CrossRef]

152. Ritchie, H.; Stothard, E.; Wright, K.J. Entrainment of the human circadian clock to the light-dark cycle and its impact on patients in the ICU and nursing home settings. Curr. Pharma. Des. 2015, 21, 3438-3442. [CrossRef]

153. Munch, M.; Schmieder, M.; Bieler, K.; Goldbach, R.; Fuhrmann, T.; Zumstein, N.; Vonmoos, P.; Scartezzini, J.; Wirz-Justice, A.; Cajochen, C. Bright light delights: Effects of daily light exposure on emotions, rest-activity cycles, sleep and melatonin secretion in severely demented patients. Curr. Alzheimer Res. 2017, 14, 1063-1075.

154. Gies, P.; van Deventer, E.; Green, A.; Sinclair, C.; Tinker, R. Review of the global solar UV index 2015 workshop report. Health Phys. 2018, 114, 84-90. [CrossRef]

155. Lanca, C.; Teo, A.; Vivagandan, A.; Htoon, H.; Najjar, R.; Spiegel, D.; Pu, S.; Saw, S. The effects of different outdoor environments, sunglasses and hats on light levels: Implications for myopia prevention. Transl. Vis. Sci. Technol. 2019, 8, 7. [CrossRef]

156. Phillips, A.; Vidafar, P.; Burns, A.; McGlashan, E.; Anderson, C.; Rajaratnam, S.; Lockley, S.; Cain, S. High sensitivity and interindividual variability in the response of the human circadian system to evening light. Proc. Natl. Acad. Sci. USA 2019, 116, 12019-12024. [CrossRef]

157. McGlashan, E.; Poudel, G.; Vidafar, P.; Drummond, S.; Cain, S. Imaging individual differences in the response of the human suprachiasmatic area to light. Front. Neurol. 2018, 9, 1022. [CrossRef] [PubMed]

158. Watson, L.; Phillips, A.K.; Hosken, I.; McGlashan, E.; Anderson, C.; Lack, L.; Lockley, S.; Rajaratnam, S.M.; Cain, S. Increased sensitivity of the circadian system to light in delayed sleep-wake phase disorder. J. Physiol. London 2018, 596, 6249-6261. [CrossRef] [PubMed]

159. Akacem, L.; Wright, K., Jr.; LeBourgeois, M. Sensitivity of the circadian system to evening bright light in preschool-age children. Physiol. Rep. 2018, 6, e13617. [CrossRef] [PubMed]

160. Higuchi, S.; Nagafuchi, Y.; Lee, S.I.; Harada, T. Influence of light at night on melatonin suppression in children. J. Clin. Endocrinol. Metab. 2014, 99, 3298-3303. [CrossRef]

161. Nagare, R.; Rea, M.S.; Plitnick, B.; Figueiro, M. Nocturnal melatonin suppression by adolescents and adults for different levels, spectra, and durations of light exposure. J. Biol. Rhythm. 2019, 34, 178-194. [CrossRef] 
162. Chellappa, S.; Bromundt, V.; Frey, S.; Steinemann, A.; Schmidt, C.; Schlote, T.; Goldblum, D.; Cajochen, C. Association of intraocular cataract lens replacement with circadian rhythms, cognitive function, and sleep in older adults. JAMA Ophthalmol. 2019, 137, 878-885. [CrossRef]

163. Turner, P.L.; Mainster, M.A. Circadian photoreception: Ageing and the eye's important role in systemic health. Br. J. Ophthalmol. 2008, 92, 1439-1444. [CrossRef]

164. Münch, M.; Ladaique, M.; Roemer, S.; Hashemi, K.; Kawasaki, A. Melanopsin-mediated acute light responses measured in winter and in summer: Seasonal variations in adults with and without cataracts. Front. Neurol. 2017, 8, 464. [CrossRef]

165. Najjar, R.; Chiquet, C.; Teikari, P.; Cornut, P.; Claustrat, B.; Denis, P.; Cooper, H.; Gronfier, C. Aging of non-visual spectral sensitivity to light in humans: Compensatory mechanisms? PLoS ONE 2014, 9, e85837. [CrossRef]

166. Daneault, V.; Vandewalle, G.; Hébert, M.; Teikari, P.; Mure, L.; Doyon, J.; Gronfier, C.; Cooper, H.; Dumont, M.; Carrier, J. Does pupil constriction under blue and green monochromatic light exposure change with age? J. Biol. Rhythm. 2012, 27, 257-264. [CrossRef]

167. Park, J.; Moura, A.; Raza, A.; Rhee, D.; Kardon, R.; Hood, D. Toward a clinical protocol for assessing rod, cone, and melanopsin contributions to the human pupil response. Investig. Ophthalmol. Vis. Sci. 2011, 52, 6624-6635. [CrossRef] [PubMed]

168. Wang, B.; Shen, C.; Zhang, L.; Qi, L.; Yao, L.; Chen, J.; Yang, G.; Chen, T.; Zhang, Z. Dark adaptation-induced changes in rod, cone and intrinsically photosensitive retinal ganglion cell (ipRGC) sensitivity differentially affect the pupil light response (PLR). Graefes Arch. Clin. Exp. Ophthalmol. 2015, 253, 1997-2005. [CrossRef] [PubMed]

169. Yuhas, P.; Shorter, P.; McDaniel, E.; Earley, M.; Hartwick, A. Blue and red light-evoked pupil responses in photophobic subjects with TBI. Optom. Vis. Sci. 2017, 94, 108-117. [CrossRef] [PubMed]

170. Kardon, R.; Hong, S.; Kawasaki, A. Entrance pupil size predicts retina illumination in darkly pigmented eyes but not lightly pigmented eyes. Investig. Ophthalmol. Vis. Sci. 2013, 54, 5559-5567. [CrossRef]

171. Kankipati, L.; Girkin, C.; Gamlin, P. The post-illumination pupil response is reduced in glaucoma patients. Investig. Ophthalmol. Vis. Sci. 2011, 52, 2287-2292. [CrossRef]

172. Münch, M.; Léon, L.; Collomb, S.; Kawasaki, A. Comparison of acute non-visual bright light responses in patients with optic nerve disease, glaucoma and healthy controls. Sci. Rep. 2015, 5, 15185. [CrossRef]

173. Rukmini, A.; Milea, D.; Baskaran, M.; How, A.; Perera, S.; Aung, T.; Gooley, J. Pupillary responses to high-irradiance blue light correlate with glaucoma severity. Ophthalmology 2015, 122, 1777-1785. [CrossRef]

174. Perez-Rico, C.; de la Villa, P.; Arribas-Gomez, I.; Blanco, R. Evaluation of functional integrity of the retinohypothalamic tract in advanced glaucoma using multifocal electroretinography and light-induced melatonin suppression. Exp. Eye Res. 2010, 91, 578-583. [CrossRef]

175. Maynard, M.; Zele, A.; Feigl, B. Melanopsin-mediated post-illumination pupil response in early age-related macular degeneration. Investig. Ophthalmol. Vis. Sci. 2015, 56, 6906-6913. [CrossRef]

176. Barboni, M.T.S.; Bueno, C.; Nagy, B.; Maia, P.; Vidal, K.; Alves, R.; Reiter, R.J.; do Amaral, F.; Cipolla-Neto, J.; Ventura, D. Melanopsin system dysfunction in Smith-Magenis syndrome patients. Investig. Ophthalmol. Vis. Sci. 2018, 59, 362-369. [CrossRef]

177. Bullock, B.; McGlashan, E.M.; Burns, A.; Lu, B.; Cain, S. Traits related to bipolar disorder are associated with an increased post-illumination pupil response. Psychiatry Res. 2019, 278, 35-41. [CrossRef] [PubMed]

178. Roecklein, K.; Wong, P.; Ernecoff, N.; Miller, M.; Donofry, S.; Kamarck, M.; Wood-Vasey, W.; Franzen, P. The post illumination pupil response is reduced in seasonal affective disorder. Psychiatry Res. 2013, 210, 150-158. [CrossRef] [PubMed]

179. Dumpala, S.; Zele, A.; Feigl, B. Outer retinal structure and function deficits contribute to circadian disruption in patients with type 2 diabetes. Investig. Ophthalmol. Vis. Sci. 2019, 60, 1870-1878. [CrossRef] [PubMed]

180. McGlashan, E.; Nandam, L.; Vidafar, P.; Mansfield, D.; Rajaratnam, S.; Cain, S. The SSRI citalopram increases the sensitivity of the human circadian system to light in an acute dose. Psychopharmacology 2018, 235, 3201-3209. [CrossRef] [PubMed]

181. Turco, M.; Biscontin, A.; Corrias, M.; Caccin, L.; Bano, M.; Chiaromanni, F.; Salamanca, M.; Mattei, D.; Salvoro, C.; Mazzotta, G.; et al. Diurnal preference, mood and the response to morning light in relation to polymorphisms in the human clock gene PER3. Sci. Rep. 2017, 7, 6967. [CrossRef] [PubMed] 
182. Azzi, A.; Dallmann, R.; Casserly, A.; Rehrauer, H.; Patrignani, A.; Maier, B.; Kramer, A.; Brown, S. Circadian behavior is light-reprogrammed by plastic DNA methylation. Nat. Neurosci. 2014, 17, 377-382. [CrossRef]

183. Roecklein, K.; Rohan, K.; Duncan, W.; Rollag, M.; Rosenthal, N.; Lipsky, R.; Provencio, I. A missense variant (P10L) of the melanopsin (OPN4) gene in seasonal affective disorder. J. Affect. Disord. 2009, 114, 279-285. [CrossRef]

184. Lee, S.; Hida, A.; Tsujimura, S.; Morita, T.; Mishima, K.; Higuchi, S. Association between melanopsin gene polymorphism (I394T) and pupillary light reflex is dependent on light wavelength. J. Physiol. Anthropol. 2013, 32, 16. [CrossRef]

185. Pereira, D.; Tufik, S.; Louzada, F.; Benedito-Silva, A.; Lopez, A.R.; Lemos, N.; Korczak, A.; D'Almeida, V.; Pedrazzoli, M. Association of the length polymorphism delayed sleep-phase syndrome: Does in the human Per3 gene with the latitude have an influence upon it? Sleep 2005, 28, 29-32.

186. Mendes, M.; Darling, A.; Hart, K.; Morse, S.; Murphy, R.J.; Lanham-New, S. Impact of high latitude, urban living and ethnicity on 25-hydroxyvitamin D status: A need for multidisciplinary action? J. Steroid Biochem. Mol. Biol. 2019, 188, 95-102. [CrossRef]

187. Grant, W.; Bhattoa, H.; Pludowski, P. Determinants of Vitamin D Deficiency From Sun Exposure: A Global Perspective. In Vitamin D, 4th ed.; Feldman, D., Ed.; Academic Press: New York, NY, USA, 2018; pp. 79-90.

188. Darling, A.; Hart, K.; Arber, S.; Berry, J.; Morgan, P.; Middleton, B.; SA, L.-N.; Skene, D. 25-Hydroxyvitamin D status, light exposure and sleep quality in UK dwelling South Asian and Caucasian postmenopausal women. J. Steroid Biochem. Mol. Biol. 2019, 189, 265-273. [CrossRef] [PubMed]

189. van der Meijden, W.; Van Someren, J.; Te Lindert, B.; Bruijel, J.; van Oosterhout, F.; Coppens, J.; Kalsbeek, A.; Cajochen, C.; Bourgin, P.; Van Someren, E. Individual differences in sleep timing relate to melanopsin-based phototransduction in healthy adolescents and young adults. Sleep 2016, 39, 1305-1310. [CrossRef] [PubMed]

190. Leger, D.; Bayon, V.; Elbaz, M.; Philip, P.; Choudat, D. Underexposure to light at work and its dissociation to insomnia and sleepiness: A cross-sectional study of 13296 workers of one transportation company. J. Psychosom. Res. 2011, 70, 29-36. [CrossRef] [PubMed]

191. Rufiange, M.; Beaulieu, C.; Lachapelle, P.; Dumont, M. Circadian light sensitivity and rate of retinal dark adaptation in indoor and outdoor workers. J. Biol. Rhythm. 2007, 22, 454-457. [CrossRef]

192. Daugaard, S.; Markvart, J.; Bonde, J.; Christoffersen, J.; Garde, A.; Hansen, A.; Schlunssen, V.; Vestergaard, J.; Vistisen, H.; Kolstad, H. Light exposure during days with night, outdoor, and indoor work. Ann. Work Expo. Health 2019, 63, 651-665. [CrossRef]

193. Chellappa, S.; Steiner, R.; Oelhafen, P.; Cajochen, C. Sex differences in light sensitivity impact on brightness perception, vigilant attention and sleep in humans. Sci. Rep. 2017, 7, 14215. [CrossRef]

194. Abramov, I.; Gordon, J.; Feldman, O.; Chavarga, A. Sex and vision II: Color appearance of monochromatic lights. Biol. Sex Differ. 2012, 3, 21. [CrossRef]

195. Rao, S.; Chun, C.; Fan, J.; Kofron, J.; Yang, M.B.; Hegde, R.; Ferrara, N.; Copenhagen, D.; Lang, R. A direct and melanopsin-dependent fetal light response regulates mouse eye development. Nature 2013, 494, 243-246. [CrossRef]

196. Cambras, T.; Canal, M.; Cernuda-Cernuda, R.; Garcia-Fernandez, J.; Diez-Noguera, A. Darkness during early postnatal development is required for normal circadian patterns in the adult rat. Chronobiol. Int. 2015, 32, 178-186. [CrossRef]

197. Kerkhof, G.; Korving, H.; Willemse-vd Geest, H.; Rietveld, W. Diurnal differences between morning-type and evening-type subjects in self-rated alertness, body temperature and the visual and auditory evoked potential. Neurosci. Lett. 1980, 1, 11-15. [CrossRef]

198. Horne, J.A.; Östberg, O. A self-assessment questionnaire to determine morningness-eveningness in human circadian rhythms. Int. J. Chronobiol. 1976, 4, 97-110. [PubMed]

199. Porcheret, K.; Wald, L.; Fritschi, L.; Gerkema, M.; Gordijn, M.; Merrrow, M.; Rajaratnam, S.; Rock, D.; Sletten, T.; Warman, G.; et al. Chronotype and environmental light exposure in a student population. Chronobiol. Int. 2018, 35, 1365-1374. [CrossRef] [PubMed]

200. Roenneberg, T. Having trouble typing? What on earth Is chronotype? J. Biol. Rhythm. 2015, 30, $487-491$. [CrossRef] [PubMed]

201. Roenneberg, T.; Wirz-Justice, A.; Merrow, M. Life between clocks: Daily temporal patterns of human chronotypes. J. Biol. Rhythm. 2003, 18, 80-90. [CrossRef] 
202. Goulet, G.; Mongrain, V.; Desrosiers, C.; Paquet, J.; Dumont, M. Daily light exposure in morning-type and evening-type individuals. J. Biol. Rhythm. 2007, 22, 151-158. [CrossRef]

203. Shochat, T.; Santhi, N.; Herer, P.; Flavell, S.; Skeldon, A.; Dijk, D. Sleep timing in late autumn and late spring associates with light exposure rather than sun time in college students. Front. Neurosci. 2019, 13, 882. [CrossRef]

204. Dumont, M.; Blais, H.; Roy, J.; Paquet, J. Controlled patterns of daytime light exposure improve circadian adjustment in simulated night work. J. Biol. Rhythm. 2009, 24, 427-437. [CrossRef]

205. Matusiak, B.S.; Klöckner, C.A. How we evaluate the view out through the window. Archit. Sci. Rev. 2016, 59, 203-211. [CrossRef]

206. Ulrich, R. Biophilia, biophobia, and natural landscapes. In The Biophilia Hypothesis; Kellert, S.R., Wilson, E., Eds.; Island Press: Washington, DC, USA, 1993; pp. 73-137.

207. Vondrasova, D.; Hajek, I.; Illnerova, H. Exposure to long summer days affects the human melatonin and cortisol rhythms. Brain Res. 1997, 759, 166-170. [CrossRef]

208. Hadlow, N.; Brown, S.; Wardrop, R.; Conradie, J.; Henley, D. Where in the world? Latitude, longitude and season contribute to the complex co-ordinates determining cortisol levels. Clin. Endocrinol. Oxf 2018, 89, 299-307. [CrossRef]

209. Eastman, C.I. Natural summer and winter sunlight exposure patterns in seasonal affective disorder. Physiol. Behav. 1990, 48, 611-616. [CrossRef]

210. Graw, P.; Recker, S.; Sand, L.; Kräuchi, K.; Wirz-Justice, A. Winter and summer outdoor light exposure in women with and without seasonal affective disorder. J. Affect. Disord. 1999, 56, 163-169. [CrossRef]

211. Hadlow, N.; Brown, S.; Wardrop, R.; Henley, D. The effects of season, daylight saving and time of sunrise on serum cortisol in a large population. Chronobiol. Int. 2014, 31, 243-251. [CrossRef] [PubMed]

212. Roenneberg, T.; Wirz-Justice, A.; Skene, D.J.; Ancoli-Israel, S.; Wright, K.P.; Dijk, D.J.; Zee, P.; Gorman, M.R.; Winnebeck, E.; Klerman, E. Why should we abolish daylight saving time? J. Biol. Rhythm. 2019, 34, 227-230. [CrossRef] [PubMed]

213. Roenneberg, T.; Winnebeck, E.; Klerman, E. Daylight saving time and artificial time zones-a battle between biological and social times. Front. Physiol. 2019, 10, 944. [CrossRef] [PubMed]

214. Kantermann, T.; Juda, M.; Merrow, M.; Roenneberg, T. The human circadian clock's seasonal adjustment is disrupted by daylight saving time. Curr. Biol. 2007, 17, 1996-2000. [CrossRef] [PubMed]

215. Borisenkov, M.; Tserne, T.; Panev, A.; Kuznetsova, E.; Petrova, N.; Timonin, V.; Kolomeichuk, S.; Vinogradova, I.; Kovyazina, M.; Khokhlov, N.; et al. Seven-year survey of sleep timing in Russian children and adolescents: Chronic 1-h forward transition of social clock is associated with increased social jetlag and winter pattern of mood seasonality. Biol. Rhythm. Res. 2017, 48, 3-12. [CrossRef]

216. Andersen, M. Unweaving the human response in daylighting design. Build. Environ. 2015, 91, $101-117$. [CrossRef]

217. van Duijnhoven, J.; Aarts, M.P.; Aries, M.B.; Rosemann, A.; Kort, H. Systematic review on the interaction between office light conditions and occupational health: Elucidating gaps and methodological issues. Indoor Built Environ. 2019, 28, 152-174. [CrossRef]

218. Dubois, M.; Cantin, F.; Johnsen, K. The effect of coated glazing on visual perception: A pilot study using scaleamodels. Lighting Res. Technol. 2007, 39, 283-304. [CrossRef]

219. Dong, B.; Prakash, V.; Feng, F.; O'Neill, Z. A review of smart building sensing system for better indoor environment control. Energy Build. 2019, 199, 29-46. [CrossRef]

220. Pasanen, T.; Tyrvainen, L.; Korpela, K. The relationship between perceived health and physical activity indoors, outdoors in built environments, and outdoors in nature. Appl. Psychol. Health Well Being 2014, 6, 324-346. [CrossRef] [PubMed]

221. Takayama, N.; Korpela, K.; Lee, J.; Morikawa, T.; Tsunetsugu, Y.; Park, B.J.; Li, Q.; Tyrvainen, L.; Miyazaki, Y.; Kagawa, T. Emotional, restorative and vitalizing effects of forest and urban environments at four sites in Japan. Int. J. Environ. Res. Public Health 2014, 11, 7207-7230. [CrossRef] [PubMed]

222. Donovan, G.; Gatziolis, D.; Douwes, J. Relationship between exposure to the natural environment and recovery from hip or knee arthroplasty: A New Zealand retrospective cohort study. BMJ. Open 2019, 9, e029522. [CrossRef] 
223. Nang, E.; Abuduxike, G.; Posadzki, P.; Divakar, U.; Visvalingam, N.; Nazeha, N.; Dunleavy, G.; Christopoulos, G.; Soh, C.; Jarbrink, K.; et al. Review of the potential health effects of light and environmental exposures in underground workplaces. Tunn. Undergr. Space Technol. 2019, 84, 201-209. [CrossRef]

224. Spitschan, M.; Stefani, O.; Blattner, P.; Gronfier, C.; Lockley, S.; Lucas, R. How to report light exposure in human chronobiology and sleep research experiments. Clocks Sleep 2019, 1, 280-289. [CrossRef]

225. International Commissoin on Illumination. CIE System for Metrology of Optical Radiation for ipRGC-Influenced Responses to Light; CIE: Vienna, Austria, 2018.

226. World Health Organization. Implementation framework for phase VII (2019-2014) of the WHO European Healthy Cities Network: Goals, Requirements and Strategic Approaches. Available online: http://www.euro.who.int/en/health-topics/environment-and-health/urban-health/who-europeanhealthy-cities-network (accessed on 10 October 2019).

227. World Health Organization. Health 21-Health for all in the 21st Century: An Introduction; World Health Organization Europe: Copenhagen, Denmark, 2019.

228. Lucas, R.; Peirson, S.; Berson, D.; Brown, T.; Cooper, H.; Czeisler, C.; Figueiro, M.; Gamlin, P.; Lockley, S.; O'Hagan, J.; et al. Measuring and using light in the melanopsin age. Trends Neurosci. 2014, 37, 1-9. [CrossRef]

229. Markvart, J.; Hansen, Å.; Christoffersen, J. Comparison and correction of the light sensor output from 48 wearable light exposure devices by using a side-by-side field calibration method. Leukos 2015, 11, 155-171. [CrossRef]

230. Figueiro, M.; Hamner, R.; Bierman, A.; Rea, M. Comparisons of three practical field devices used to measure personal light exposures and activity levels. Lighting Res. Technol. 2013, 45, 421-434. [CrossRef]

(C) 2020 by the authors. Licensee MDPI, Basel, Switzerland. This article is an open access article distributed under the terms and conditions of the Creative Commons Attribution (CC BY) license (http://creativecommons.org/licenses/by/4.0/). 